DALKIN, ROBERT NIXON (BOB) (1914-1991), air force officer and territory administrator, was born on 21 February 1914 at Whitley Bay, Northumberland, England, younger son of English-born parents George Nixon Dalkin, rent collector, and his wife Jennie, née Porter. The family migrated to Australia in 1929. During the 1930s Robert served in the Militia, was briefly a member of the right-wing New Guard, and became business manager (1936-40) for W. R. Carpenter [q.v.7] \& Co. (Aviation), New Guinea, where he gained a commercial pilot's licence. Described as 'tall, lean, dark and impressive [with a] well-developed sense of humour, and a natural, easy charm' (NAA A12372), Dalkin enlisted in the Royal Australian Air Force (RAAF) on 8 January 1940 and was commissioned on 4 May. After a period instructing he was posted to No. 2 Squadron, Laverton, Victoria, where he captained Lockheed Hudson light bombers on reconnaissance duties. On 28 December 1940 at St John's Church, Melbourne, he married Welsh-born Helen James, a bookkeeper, with Church of England rites.

Promoted to flight lieutenant on 1 January 1942, Dalkin became a flight commander in No. 13 Squadron, Darwin, in March, again flying Hudsons. During the next seven months he flew numerous strikes against Japanese targets. On 30 June, after leading four aircraft on a night attack against Koepang, Timor, in which eight enemy aircraft were possibly destroyed, Dalkin was awarded the Distinguished Flying Cross. The citation commended his leadership and courage in the face of heavy anti-aircraft fire. From October 1944 , as an acting wing commander, he was attached to the Royal Air Force's Bomber Command in Britain to develop techniques the RAAF might adopt in the Pacific.

Following demobilisation on 5 March 1946, Dalkin became chief ground instructor for Trans Australia Airlines, but rejoined the $\mathrm{RAAF}$ as a squadron leader with a permanent commission on 26 September. Respected for his clear thinking and integrity, he was promoted to group captain on 1 January 1956. In this rank he progressed through a series of influential posts, including commandant of both the RAAF College (1955-56) and Staff College
(1960-61), staff officer operations, Home Command (1957-59), and officer commanding the RAAF Base, Williamtown, New South Wales (1963). He had graduated from the RAF Staff College (1950) and the Imperial Defence College (1962). Simultaneously, he maintained operational proficiency, flying Canberra bombers and Sabre fighters.

At his own request Dalkin retired with the rank of honorary air commodore from the RAAF on 4 July 1968 to become administrator (1968-72) of Norfolk Island. His tenure coincided with a number of important issues, including changes in taxation, the expansion of tourism, and an examination of the special position held by islanders.

Dalkin overcame a modest school education to study at The Australian National University (BA, 1965; MA, 1978). Following retirement, he wrote Colonial Era Cemetery of Norfolk Island (1974) and his (unpublished) memoirs. He was active in Legacy and the RAAF Women's Association Education Patriotic Fund. Bob Dalkin would often say, 'Australia's been good to me'. Survived by his wife and two children, he died of cancer in Canberra on 18 November 1991 and was cremated. His medals and a wartime sketch by Roy Hodgkinson are held by the Australian War Memorial.

Gillison, Douglas. Royal Australian Air Force 1939-1942. Canberra: Australian War Memorial, 1962; National Archives of Australia. A12372, Dalkin, R. N; Sydney Morning Herald. 'R. A. A. F. Pilot Wins D. F. C.' 11 July 1942, 11.

Alan Stephens

\section{DALY, FREDERICK MICHAEL} (FRED) (1912-1995), politician, was born on 13 June 1912 at Currabubula, New South Wales, ninth of eleven children of Irish-born Michael Daly, farmer and grazier, and his second wife Margaret Jane, née Howard, who was born in New South Wales. Fred's father died in 1923, resulting in the sale of the family home and 8,000-acre (3,200 ha) property. He moved with his mother and younger siblings from 'security' to 'poverty' at North Bondi, Sydney (Daly 1983). Educated at Currabubula and then Christian Brothers' College, Waverley, he hated school and failed 
most of his examinations. He left at about age thirteen to become a messenger and later a clerk with the bicycle manufacturer Bennett \& Wood Ltd. In World War II the manpower authorities directed him to clerical duties for the Department of the Navy. An observant Catholic, he became involved in the Mary Immaculate (Waverley) Literary, Debating, and Social Society. At a local dance he met Teresa Armstrong (d. 1975), a stenographer at the Commonwealth Department of the Treasury. They would marry on 4 October 1937 at Holy Cross Church, Woollahra.

Although his father had been a political conservative, Daly was drawn to Labor politics. He joined the Waverley branch of the Australian Labor Party (ALP) in the early 1930s, becoming active at branch, State electorate council, and Federal electorate council levels, and served on the management committee of the New South Wales branch of the Federated Clerks' Union of Australia. In 1943 he gained preselection for Martin, a Federal electorate in Sydney's west held by the United Australia Party. He won the marginal seat and retained it three years later by focusing on local community needs. To this end, he was one of the first to establish an office in his electorate to meet constituents. Following an electoral redistribution, he moved in 1949 to the new seat of Grayndler, centred on the suburbs of Newtown and Marrickville, and held it until his retirement.

In parliament, Daly was a keen student of veterans such as James Scullin [q.v.11], Ben Chifley [q.v.13], and Billy Hughes [q.v.9]. His youth and the depth of talent in Labor's ranks meant he had no opportunity to serve as a minister in his early years. He was a member of the joint committee on social security (1943-46) and the Rationing Commission (1946-50). He also represented the government at the 1947 International Labour Organisation's inland transport and coal mines committee meetings in Geneva, Switzerland, earning the nickname 'Dilly Dally Daly' for the extended time it took for his return. He was a willing advocate for controversial Labor causes, campaigning for the 1947 Banking Act, and putting the Chifley government's case against the 1949 coal strike.

Following Labor's election loss in 1949, Daly became Opposition whip, was elected to the State executive, and was identified by some as a future leader. Chifley's death in 1951 was a setback, since Daly lost his closest mentor. He also had to deal with a 'Machiavellian' leader in H. V. Evatt [q.v.14] (Daly 1983). Tensions between them came to a head in caucus on 20 October 1954, when Daly voted for a spill motion against Evatt's leadership. His vote, together with his role in the State executive's resistance to Federal intervention against the Victorian Labor branch, saw him labelled as part of the 'grouper' faction. $\mathrm{He}$ lost friends and was left in a precarious political position. Unable to work with Evatt, he did not renominate as whip in 1956.

Daly only 'began to enjoy politics again' after 1963 (1977, 163), when he joined Labor's shadow ministry, shifting between the social services and immigration portfolios. Although he harboured thoughts that he might lead the ALP, he also sensed that his opportunity had passed. He ran unsuccessfully for the leadership in 1967 . His conservative views on social issues were now increasingly out of step with the new generation in the party. In 1971 Gough Whitlam, the Opposition leader, removed him from shadowing the immigration portfolio after Daly publicly criticised Whitlam over his stance on Asian immigration. When Labor won the 1972 election, Daly was one of just four in his party who had sat on the government benches in the 1940s.

Appointed minister for services and property and leader of the House, Daly reformed electoral laws and parliamentary practices. He introduced the Commonwealth electoral bill 1973 which entitled eighteenyear-olds to vote. The Opposition's resistance to Labor's further electoral bills would contribute to the double dissolution elections in 1974 and 1975. As leader of the House, he led the arrangements for the historic joint sitting of parliament in August 1974, and he improved facilities for members, including ending all-night sittings. He was ruthless in his use of the gag and other measures to keep the government's ambitious legislative program moving through the House of Representatives.

As a key Labor strategist, Daly attended the meeting early on 11 November 1975 with coalition leaders that failed to resolve the deadlock over the supply bills, hours before the governor-general, Sir John Kerr [q.v.], dismissed the Whitlam government. Informed of the dismissal, he helped to prepare Labor's 
response. Like the other party leaders present, he focused on the House of Representatives and overlooked the Senate, failing to inform its ALP leader, Ken Wriedt, of the situation. Daly controlled the numbers in the House that afternoon, defeating the coalition in five divisions; however, this proved to be irrelevant, since the Senate had passed the supply bills.

Owing to his wife's illness and death, Daly had been contemplating retirement. He did not contest the 1975 election. Moving to Canberra, he quickly became a local celebrity. He devised a political discovery tour of the city, and published three successful books on aspects of his career: From Curtin to Kerr (1977), A to $Z$ of Politics (1978), and The Politician Who Laughed (1982). In 1981 he helped to lead the successful Canberra Raiders bid to enter the New South Wales Rugby League competition and became club co-patron. Appointed $\mathrm{AO}$ in 1978 , he was crowned 'King of Canberra' in 1981 and 1982, and was made patron of the Canberra Labor Club in 1989. He continued to campaign for the ALP and in 1995 was made a life member of the party.

Despite his public image as a convivial larrikin who lacked formal education, Daly was recognised by his colleagues as a tough adversary who used quick-witted oratory, extensive political knowledge, and tactical shrewdness to devastating effect. He maintained friendships across party lines, notably with the Liberal politician Sir James Killen. Survived by his daughter and son, Daly died at Bondi Junction, Sydney, on 2 August 1995 and was buried in Rookwood cemetery, following a state funeral at St Brigid's Church, Marrickville.

Brown, Wallace. 'In the Upper House.' Courier Mail (Brisbane), 3 August 1995, 10; Daly, Fred. From Curtin to Kerr. South Melbourne, Vic.: Sun, 1977; Daly, Frederick. Interviews by Vivienne RaeEllis, 2 August-19 September 1983. Transcript. Parliament's oral history project. National Library of Australia; Faulkner, John, and Stuart Macintyre, eds. True Believers: The Story of the Parliamentary Labor Party. Crows Nest, NSW: Allen and Unwin, 2001; MacCallum, Mungo. 'The Politician Who Could Not Hate.' Australian, 3 August 1995, 13; National Library of Australia. MS 9300, Papers of Fred Daly, 1938-1995; Reid, Alan. The Whitlam Venture. Melbourne: Hill of Content, 1976.

RodNey SMITH
DANAHER, PHYLLIS MAY (19081991), ballet teacher and examiner, was born on 27 July 1908 at Bulimba, Brisbane, eldest of four children and only daughter of Queensland-born parents William Patrick Danaher, clerk and later prominent bookmaker, and his wife Ivy May, née Bagnall. Educated at St Margaret's Church of England Girls' School, Ascot, Phyllis began her dance training in the early 1920s with Margaret St Ledger, who taught fancy and ballroom dancing, and deportment. From 1927 she studied with, and (initially without pay) taught for, Marjorie Hollinshed, who had taken over St Ledger's school. She also studied dance with Frances Scully in Sydney.

Danaher was an extra in the Brisbane performances of the Pavlova company during its 1929 tour and she appeared in J. C. Williamson's [q.v.6] musicals in Brisbane in the 1930s. She co-owned Hollinshed's school from 1930. After Hollinshed's retirement, she became principal of the school, at first in partnership with Judith Avery (1933), then with Clare O’Bryen (1934-47); subsequently, she was sole owner of the Phyllis Danaher School of Ballet. In 1935 she gained her elementary certificate in the first Royal Academy of Dancing (RAD) examinations held in Australia, and two years later secured the RAD advanced teacher's certificate.

In 1937 Danaher became the first deputy organiser for Queensland of the advisory committee to the RAD, as well as founding president of the Queensland branch of the Australasian Society of Operatic Dancing, later the Queensland Ballet Society. In 1953 the society established the Brisbane Ballet Theatre to provide local students with professionalstandard performance opportunities. From 1956 Danaher was recognised as its regisseur (stage director). She choreographed the company's first original work, The Wasps performed in 1956 at Brisbane City Hall, followed by Variations Symphoniques (first performed 1957), The Legend of Roksanda (1959), and The Willow Pattern (1962). The company was renamed Ballet Theatre of Queensland (BTQ) in 1963 with Danaher as its director; that year she choreographed Pinocchio and Italienne Fantasia. Danaher produced and directed ballets for BTQ from the 1960 s to the early 1980 s, and also designed 
costumes for the company. She produced Graduation Ball in 1970 for the North Queensland Ballet's opening season.

Danaher had become a children's examiner for the RAD in 1957, a role she maintained until her retirement from teaching in 1982. Two years later she stepped down as BTQ's director. She was appointed MBE (1969) for services to dance and made a fellow of the RAD (1983) in recognition of her service to the academy.

One of Queensland's most important ballet teachers, Danaher was a pioneer in the professionalisation of ballet learning and teaching in the State. Her students included Garth Welch and Lucette Aldous, later principal artists with the Australian Ballet. She played a major role in helping talented students realise their potential, a legacy that continues through the BTQ. Hollinshed, who described Danaher as 'one of Australia's greatest dancing teachers', concluded that 'Phyl has devoted her life' to ballet. Recalling 'a grace and softness about her movements', Hollinshed remembered that as a young teacher she had spoken in 'almost a whisper', not 'at all like the later Miss Phyllis Danaher, M.B.E., F.R.A.D.' (Hollinshed 1987, 39, 55, 114). Danaher overcame her early shyness, with her students remembering her as a strict disciplinarian and a 'no-nonsense' teacher (Koch, 34). Unmarried, she died on 31 May 1991 at Clayfield, Brisbane, and was buried at Lutwyche cemetery with Catholic rites. The Phyllis Danaher memorial scholarship is awarded annually to a BTQ dancer.

Ballet and Dance-Ballet Theatre of Queensland, formerly Queensland Ballet Society: ephemera material collected by the State Library of Queensland; Brissenden, Alan, and Keith Glennon. Australia Dances: Creating Australian Dance 19451965. Kent Town, SA: Wakefield Press, 2010; Hollinshed, Marjorie. Some Professional Dancers of, or from, Queensland and Some Teachers of the Past and Present. Brisbane: W. R. Smith \& Paterson Pty Ltd, 1963; Hollinshed, Marjorie. In Search of Ballet. Caloundra, Qld: Boolarong Publications, 1987; Koch, Peta. 'Brisbane's No-Nonsense Teacher.' Dance Australia 33 (December 1987 - January 1988): 34; Pask, Edward H. Ballet in Australia: The Second Act 1940-1980. Melbourne: Oxford University Press, 1982.

JOANNE SCOTT
DANIEL, WILLIAM JOSEPH (BILL) (1930-1994), Jesuit priest, theologian, and teacher, was born on 26 April 1930 in Melbourne, second of four children of Thomas Francis Daniel, public servant, and his wife Eileen Catherine, née Mooney. His father, who had been dux of Assumption College, Kilmore, was a clerk in the Department of Defence; he transferred from Melbourne to Sydney by 1934. Bill attended Brigidine Convent, Randwick (1935-36), St Patrick's College, Strathfield (1937-41), and St Ignatius' College, Riverview, Sydney (1942-46). He entered the novitiate of the Society of Jesus on 1 February 1947 at Loyola College, Watsonia, Victoria.

Daniel began his seventeen years of training with two years study of Jesuit spirituality, after which he took initial vows of poverty, chastity, and obedience. Then followed studies of philosophy at Loyola College (1950-52), and of Latin, Greek, and French at the University of Melbourne (BA, 1957; MA, 1958). Graduating with firstclass honours, he studied Homeric religion for his master's degree, while teaching Greek at Loyola College, and tutoring in Latin at the university.

As a break from his studies, Daniel had spent 1953 teaching at St Ignatius' College and in 1958 he was at St Louis School, Claremont, Perth, where he was sports master, teacher of Latin and religion, and director of a religious group for junior students. He then studied theology (1959-62) at Canisius College, Pymble, Sydney, and was ordained by Cardinal (Sir) Norman Gilroy [q.v.14] on 3 January 1962 at St Mary's Church, North Sydney. In 1963 Daniel taught Latin and spiritualty at Corpus Christi College, Werribee, Victoria, before undertaking his last year of spiritual training at Münster, Germany. He took his final vows on 2 February 1965.

Pursuing postgraduate studies in moral theology (1965-66) at the Gregorian University, Rome, Daniel wrote a doctoral thesis, published in 1968, on 'The Purely Penal Law Theory in Spanish Theologians from Vitoria to Suárez'. He returned to Canisius College in 1967 to teach moral theology. In 1969 the Jesuit theologate moved to Melbourne, where for the rest of his life Daniel taught at the Jesuit Theological College, Parkville, which was a constituent college of 
the ecumenical United Faculty of Theology. He also lectured at the Catholic Theological College, East Melbourne, and the Yarra Theological Union, Box Hill. He was elected to represent the Australian province at the Jesuits' 32nd General Congregation (197475), and from 1984 to 1990 was superior of the provincial residence at Hawthorn.

Daniel was a founding member of the Catholic Moral Theology Association of Australia and New Zealand that began in the 1970s. In the last decade of his life, he contributed regularly to theological journals including the Australasian Catholic Record, Compass Theology Review, and Pacifica, writing essays on in-vitro fertilisation (IVF), abortion, AIDS, marriage and divorce, priorities in health care, trade unions, and the 1987 Vatican instruction Donum Vitae, which outlined the Roman Catholic Church's position on biomedical issues. Several books featured chapters by Daniel, including Test Tube Babies (1982), in which he defended a church position on IVF, and Making Our Peace (1987), which included his essay 'Christians and War: The Just War in the Nuclear Age'. He discussed Aboriginal land rights and Catholic social teaching in Finding Common Ground (1985), while his final publication was an essay on Aboriginal self-determination in Reconciling Our Differences: A Christian Approach to Recognising Aboriginal Land Rights (1992). His interest in Aboriginal rights was reflected in his membership (1978-82) of the Federal government's Uranium Advisory Council, which was created after the Ranger Uranium Environmental Inquiry (1976-77).

Writing clearly and economically, Daniel related the Catholic tradition of moral theology to modern scholarship and contributed to the emerging field of bioethics. For instance, he argued that the case against IVF should be based on the need to revere parents as procreators, rather than the need for the dignified care of embryos. He based his argument on previous church doctrine, especially on Pope Paul VI's encyclical Humanae Vitae (1968) and the Congregation for the Doctrine of the Faith's 'Declaration on Procured Abortion' (1974), and he was critical of Donum Vitae.

As a person Daniel was intelligent, cultured, and humane. A man of deep rather than numerous friendships, he was a strong rather than a light-hearted, easygoing presence. He tended to drive people rather than to lead, while his reserved, formal, even pompous manner did not encourage closeness. As a teacher, he encouraged considering all perspectives on a matter before taking up a position. For a quarter of a century he was one of Australia's leading moral theologians and was widely consulted on matters of medical ethics and social justice. For his last sabbatical in 1991, he worked among the poor in Santiago, Chile, and for the Jesuit Refugee Service in Bangkok, Thailand. Diagnosed with terminal cancer in October 1992, he continued teaching while receiving treatment. He died on 23 October 1994 at the Freemasons Hospital, East Melbourne, and was buried in the Boroondara cemetery.

Begley, John. 'William Joseph Daniel (19301994).' Jesuit Life, no. 45 (April 1995): 4-10. Jesuit Province Archives, Hawthorn, Melbourne. Copy held on $A D B$ file; Byrne, Brendan. 'William Daniel.' Jesuit Life, no. 45 (April 1995): 1-3. Jesuit Province Archives, Hawthorn, Melbourne. Copy held on $A D B$ file; Jesuit Province Archives. Summarium Vitae Defuntorum. Father William Daniel, S. J.; McGirr, Michael. 'In Memoriam, William Joseph Daniel SJ, 1930-1994.' Eureka Street, November 1994: 4; Pacifica: Australian Theological Studies. 'William Daniel SJ.' 7, no. 3 (October 1994): 324; Strong, David. The Australian Dictionary of Jesuit Biography, 1848-1998. Sydney: Halstead Press, 1999, 78-79.

DAVID STRONG

\section{DANIELS, LAURENCE JOHN} (LAURIE) (1916-1994), public servant, was born at Prospect, Adelaide, on 11 August 1916, eldest of three sons of Adelaide-born parents Leslie Tinsley Daniels, commercial traveller, and his wife Margaret Bridget, née Bradley, dressmaker. With Margaret's father and her two unmarried siblings, the staunchly Catholic family lived in a lower-middle-class neighbourhood in North Adelaide. Leslie lost his job during the Depression and left to work interstate. Following earlier Catholic schooling, Laurie attended Christian Brothers' Rostrevor College, Adelaide, for two years on a State bursary, and was dux in 1933.

Highly placed in an examination for competitive entry to the Commonwealth Public Service, Daniels moved to Sydney in 1934 to commence employment in the Treasury's taxation branch. Studying part 
time over eight years, he gained accountancy qualifications and an economics degree from the University of Sydney (BEc, 1944). He married Joyce Margaret Carey, a stenographer, at St Joan of Arc Church, Haberfield, on 11 February 1943. Transferred to taxation's central office in Canberra in 1945, and promoted in 1946, the bright young officer chafed under 'an excess of legalism and rigidity' (Daniels 1981). He gained promotion to the Department of Health in 1953, becoming a senior executive in 1964 responsible for health planning and legislation.

Since 1953 a Commonwealth scheme had subsidised people's voluntary contributions to private health funds to insure against hospital and medical expenses. In 1968 the Gorton government commissioned an inquiry under Justice (Sir) John Nimmo to address the scheme's complexity, low participation rates, and high out-of-pocket expenses; Daniels was secretary. Many of Nimmo's recommendations were implemented in 1970, but the Australian Labor Party, then in Opposition, proposed bolder policy, which Dick Scotton and John Deeble, researchers at the University of Melbourne, had designed. In Federal election campaigns in 1969 and 1972, private health funds and the medical profession strenuously opposed Labor's universal and compulsory health insurance policy, named Medibankthe funds to protect their industry, and the doctors to secure the privacy of their earnings data and maintain independence from government. Labor stood its ground. In December 1972 the incoming Whitlam Labor government shifted the health insurance function, under Daniels, from the Department of Health to the new Department of Social Security to curtail doctors' influence within the bureaucracy.

Daniels was appointed director-general of the Department of Social Security in July 1973. His minister, W. G. (Bill) Hayden, was initially wary of the public service, but came to appreciate and respect his senior departmental officers, observing later: 'The Department was transformed from being dominantly a bookkeeping manager of a well-established range of benefits to an active policy department and provider of a much wider range of services than hitherto' (Hayden 1996, 182). Hayden negotiated with State governments, the medical profession, and other interested parties, and steered Medibank through Labor's cabinet and party processes. Following the Senate's rejection three times, Medibank was finally legislated during Australia's first joint sitting of parliament in August 1974. It stands as one of the signature achievements of the Whitlam government.

In December 1975 the incoming Fraser government returned health insurance to the Department of Health and subsequently wound Medibank back. Daniels continued as permanent head of social security under Minister (Dame) Margaret Guilfoyle (1975-80). The welfare system was under strain during 1976-77, the result of a sharp increase in the number of sole parents and high unemployment. Regarding supporting mothers' benefits, the department sought to balance the government's desire to restrain costs with social change and clients' rights to privacy. A High Court of Australia case, Green v. Daniels (1977), highlighted the government's efforts to tighten eligibility for unemployment benefits. At his minister's insistence, Daniels had directed that school leavers be denied benefits over the summer vacation. However, as there had been no change in legislation, the court ruled that such benefits could not validly be denied, and that each case had to be considered on its merits. Although Daniels's working relationship with Guilfoyle was mutually respectful, the government resolved to present a harder line against perceived 'dole-bludging' and transferred him to the lesser office of secretary, Department of the Capital Territory, in August 1977.

At a time when Federal government staff ceilings and budget cuts were damaging Canberra's economy, Daniels supported Robert (Bob) Ellicott, minister for the capital territory (1977-80), in promoting private enterprise locally. Initiatives included creating the Canberra Development Board and making commercial leasehold more investorfriendly. Daniels retired in August 1981. He had advised two Labor ministers (Hayden and John Wheeldon) and four Liberal ministers (Guilfoyle, Tony Staley, Ellicott, and Michael Hodgman), earning their respect for his professionalism. A steadfast man, he practised his Catholic religion all his life and provided valuable voluntary services to the Church and community. In retirement he 
continued to serve on the Commonwealth's Administrative Review Council, and hospital, health, welfare, and educational bodies of the Australian Capital Territory, including the Health Services Council and the Gaming and Liquor Authority. He was a member of the Australian Catholic University's Senate, which established a scholarship in his name in 1996. He had been appointed OBE in 1972 and CB in 1979 .

Survived by Joyce and their eight daughters and two sons, Daniels died on 16 September 1994 at Woden Valley Hospital and was buried in Gungahlin cemetery, Canberra. $\mathrm{He}$ was remembered as 'the simplifier of the great notion, the person with a good gut instinct for how something would sell, and the affable, decent and down-to-earth adviser and confidante who could get people to work together and, usually, get things to work' (Waterford 1994, 8).

Boxall, Anne-marie, and James A. Gillespie. Making Medicare: The Politics of Universal Health Care in Australia. Sydney: UNSW Press, 2013; Daniels, Laurie. Interview by Vivienne Rae-Ellis, 8-15 December 1981. Recording. National Library of Australia Oral History Collection. nla.gov.au/ nla.obj-195209022; Hayden, Bill. Hayden: An Autobiography. Sydney: Angus \& Robertson, 1996; Personal Knowledge of $A D B$ subject; Waterford, Jack. 'A Top Adviser with the Common Touch.' Canberra Times, 22 September 1994, 8.

Malcolm Wood

DARLING, SIR JAMES RALPH (18991995), headmaster, broadcasting administrator, government advisor, and columnist, was born on 18 June 1899 at Tonbridge, Kent, England, second of five surviving children and elder son of English-born Augustine (Austen) Major Darling, schoolmaster, and his Scottish wife Jane Baird, née Nimmo. James attended his father's small preparatory establishment, the Castle School, Tonbridge, then boarded at Highfield School, Liphook, Hampshire (1912-13), and Repton School, Derbyshire (1913-17). Victor Gollancz (later a founder of the Left Book Club, 1936-48) taught Darling civics at Repton, a formative experience that shaped his liberalism.

Commissioned as a second lieutenant in the Royal Field Artillery on 8 July 1918, Darling served briefly in France in World War I and was then part of the Allied occupation of Germany, before his demobilisation on 31 October 1919. At Oriel College, Oxford (BA, 1921), he read history as part of a shortened degree for ex-servicemen. He then taught at Merchant Taylors' School, Liverpool (1921-24), and Charterhouse, Surrey (192429). As a youthful idealist, he joined the Labour Party, became a borough councillor, and was active in the League of Nations Union. In 1929 he led a schoolboy tour to New Zealand and Australia, which provided him with first-hand experience of the British Empire; as a result he began to rethink his previous attitude of imperial indifference. After his return home, he was encouraged to apply for the headship of Geelong Church of England Grammar School. He was appointed and arrived at Corio, near Geelong, in February 1930.

Geelong Grammar was part of the Associated Public Schools (APS) of Victoria and widely acknowledged as bestowing social cachet on its students. Its enrolments principally comprised boys from the Western District and from Melbourne business and professional families. Darling cut an authoritative and dashing figure: tall, gaunt, smiling, boyishly engaging, and pipe-smoking. His thirty-twoyear incumbency until 1961 had a far-reaching impact: an isolated boarding school of about 300 boys grew to more than 1,000 on four sites. The council wanted it to be the great public school of Australia' (Gronn 2017, 140). To this end, Darling reorganised the timetable, revised the curriculum, and initiated a building program that included additional classrooms, a new boarding house, and a specialist art and music school. The improved facilities were intended to stimulate enrolment growth, although with few endowments such expansion was risky. He sought publicity for the school by cultivating a network of supporters among University of Melbourne professors, and encouraging national and international visitors. On 21 August 1935 at Toorak Presbyterian Church he married twenty-year-old Margaret Dunlop Campbell, whom he had met on a return voyage from England the previous year.

Darling was active beyond Geelong Grammar, especially in the cause of youth and as a tireless advocate of community centres. In 1932 he founded the Unemployed Boys' Centre in Geelong, a charitable venture. Four years later he established the Fellowship of St John in Latrobe Street, Melbourne, 
a devotional centre for old boys and students. He was appointed to major educational policy bodies in Victoria, including the Schools Board (1932), the council of the University of Melbourne (1933-71), and the Council of Public Education (1939). In 1931 he co-founded the Headmasters' Conference of Australia. With its support, he and his fellow heads helped persuade the Lyons [q.v.10] government to facilitate graduate entry to the Commonwealth Public Service. He had limited success in curbing the intensity of APS inter-school sport tribalism.

In March 1939 Darling went to England on leave but, with the outbreak of World War II, dithered about his return. He was temporarily employed in the Ministry for Information, but was disappointed by the shelving of plans for a new British governmentfunded physical education training college that he was likely to head. Suspecting that the school council was undermining his Geelong Grammar reforms, he returned to Australia in early 1940 . His glum mood was worsened by wartime stringency and the loss of masters to the armed forces.

Emigration had eroded Darling's English Labour sympathies, but not his liberalism. Pragmatically, he cultivated United Australia Party politicians including Henry Gullett [q.v.9], James Fairbairn [q.v.8], and, especially, R. G. (Baron) Casey [q.v.13], a lifelong friend; but he also built relations with Australian Labor Party politicians, in particular Arthur Calwell [q.v.13], Frank Crean, and John Dedman [q.v.13], the member for Corio. Occasionally, his liberal outlook was deemed suspect, notably in late 1942, when a student editorial in the school magazine criticised the contribution to the war effort of Australian public schools, dividing the school community. Two years earlier, Darling had employed a young master just returned from Oxford, Manning Clark [q.v.], the extent of whose left-wing influence on students raised eyebrows among some conservative old boys. Temporarily wrong-footed by accusations that he was himself 'pink', Darling stood his ground and retained Clark's services.

A sense of wartime stagnation was relieved for Darling when Dedman, minister for war organisation of industry, appointed him (1942-51) to the new Universities Commission, chaired by Professor R. C. Mills [q.v.10]. This was the first of several appointments to Federal agencies over the next three decades. In the changed postwar political climate for independent schooling, Darling convened a joint conference of independent and state headmasters, held at Corio in 1948. The next year he was one of two candidates for the post of director of education in Victoria but was not appointed. He then spearheaded a successful campaign for Federal income taxation concessions for tuition fees (1952) and gifts to schools (1954).

In the late 1940s Darling was considered for headmasterships at Stowe School, Buckinghamshire, and Shrewsbury School, Shropshire. With his hopes of a return to England having faded, he had a productive decade in the 1950s, with three educational achievements: Timbertop, the Australian College of Education, and the Marcus Oldham Farm Management College. The Timbertop venture built on the ideas of Kurt Hahn, an expatriate German educator, and Geelong Grammar's own outdoor traditions. This new mountain school near Mansfield opened in 1953 as a self-supporting, democratically run community for Geelong Grammar boys in fourth form. The Australian College of Education, founded at Corio in May 1959 with Darling as its inaugural president (1959-63), expressed his dream of elevating public recognition of the teaching profession. The Marcus Oldham Farm Management College (established in 1962) was a private fee-paying college at Highton, near Geelong, that provided practical education and estate management for graziers' sons. Darling continued to be active in such voluntary and community groups as the British Memorial Fund and the Geelong Community Chest.

With the election of successive Menziesled [q.v.15] coalition governments, Darling was appointed to a number of advisory roles. He was a member (1955-61) of the Australian Broadcasting Control Board, in which position he was active in public hearings for commercial television licences. Following the death of Sir Richard Boyer [q.v.13] in 1961, he became chairman of the Australian Broadcasting Commission, where he served two three-year terms. This role was his biggest challenge in public life and he likened it to putting his head into a hornet's nest. Amid cultural upheaval in 1960s Australia, numerous ABC 
programming controversies provoked the ire of politicians and interest groups. Frequently, Darling defended programmers against press criticisms, and the complaints of viewers and listeners, gaining the approval of senior and junior officers.

Meanwhile, Darling was appointed to the Commonwealth Immigration Advisory Council (1953-68) and the Commonwealth Immigration Publicity Council (1962-71), which he chaired. These appointments coincided with the liberalising of long-standing restrictions on non-European immigration, a process which Darling supported. On the Advisory Council he was active in the annual citizenship conventions in Canberra. Darling was also chairman (1961-71) of the Australian Road Safety Council, a committee that advised State and Commonwealth transport ministers and whose responsibilities encompassed public education on road safety. It was replaced in 1970 by the Commonwealth Expert Group on Road Safety with Darling as the inaugural chairman (1970-71). Australia's road toll peaked in 1970 and public education was one of the factors in its subsequent decrease. Darling served as chairman (1962-71) then president (1971-73) of the Australian Frontier Commission, an ecumenical initiative of the Australian Council of Churches, and was president (1973-81) of the Australian Elizabethan Theatre Trust. His last major public educational engagement (from 1972) was with the United World Colleges, a venture to create a global network of schools aimed at increasing international understanding, tolerance, and cooperation.

Darling was appointed OBE in 1953, CMG in 1958, and knighted in 1968. He received honorary degrees from Oxford (DCL, 1948), the University of Melbourne (MA, 1969; LLD, 1973), and Deakin University (DLitt, 1989), and was elected an honorary fellow (1987) by Oriel College. During the 1988 bicentenary, he was named as one of 200 Great Australians. An edited selection of Darling's speeches, The Education of a Civilized Man, had been published in 1962. He also co-authored Timbertop: An Innovation in Australian Education (1967) and wrote an autobiography, Richly Rewarding (1978). From 1980 to 1994 , he wrote columns for the Age newspaper on a variety of Christian religious and related themes. These were also republished in Reflections for the Age (1991) and Reflections for an Age (2006).

Known affectionately and variously as JRD, the boss, Dr Darling, Sir James, and Jim, and as JoJo to his grandchildren, Darling died on 1 November 1995 at Windsor, Melbourne, and was cremated. His wife and their three daughters and one son survived him. Geelong Grammar School holds a portrait of him by Hilda Rix Nicholas [q.v.11] and in 1997 established a memorial oration and scholarship fund in his name. The Victorian branch of the Australian College of Educators instituted the annual Sir James Darling medal in 1993.

Darling, James. Richly Rewarding. Melbourne: Hill of Content, 1978; Darling Papers. Private collection; Geelong Grammar School archives; Gronn, Peter. Just as I Am: A Life of J. R. Darling. Richmond, Vic.: Hardie Grant Books, 2017; National Library of Australia. MS 7826, Papers of James R. Darling, 1947-1991.

Peter Gronn

DATE, REGINALD THOMAS (19211995), footballer, was born on 26 July 1921 at Wallsend, New South Wales, second of three children of New South Wales-born parents John Thomas 'Mick' Date, coalmine wheeler and later fisherman, and his wife Nancy Annie, née Wilson, storekeeper at Lemon Tree Passage. Family life was marred by Mick's drunken rages. Nance sent Reg to live with her parents in Wallsend when the boy was eight. $\mathrm{He}$ attended Plattsburg Public (later District Rural) School, leaving with the Intermediate certificate in 1936.

Moving proved pivotal. Coal-mining Wallsend had been a centre of soccer since the 1880 s and Date's grandparents encouraged him to play. Representing his school and Wallsend, as a junior he amassed an astonishing total of approximately 1,000 goals over eight seasons. Making his senior debut in 1938, he began a goal-scoring feast unknown in Australia before or since. Appearing 336 times for Wallsend (1938-44, 1948-54) and CanterburyBankstown (1945-47), he also represented Northern Districts, New South Wales, and Australia (five caps), captaining the national team in three matches during South Africa's tour in 1947. In seventeen seasons of senior football he scored 664 goals for his clubs. On 
29 October 1947 at St Thomas Church of England, Cardiff, he married Ellen Millicent (Milcie) Wilson, a clothing machinist.

Fully grown, Date was physically imposing on the field: 5 feet 11 inches $(180 \mathrm{~cm})$ tall and weighing 176 pounds $(80 \mathrm{~kg})$. Playing centre or inside forward, he displayed ferocious and accurate goal shooting. He kicked with both feet and fearlessly shot from any angle. Bewildering acceleration and changes of pace carried him past defences: exceptional positioning denied close marking. Blessed with sporting nous, something innate but also trained by such mentors as fellow Wallsend great Alf Quill, he was an exemplary player and a target for British professional clubs, including Cardiff City, Manchester United, and Glasgow Celtic.

That Date chose not to go overseas was due to his attachment to home, the harshness of British winters, and the remuneration available in Sydney and Newcastle. In 1945 he had been paid an astounding $£ 200$ to sign for Canterbury-Bankstown and thereafter around $£ 8$ per match. In 1946 the club paid $£ 300$, and with annual match fees his salary exceeded $£ 550$. At that time the average weekly wage was $£ 6 / 9 / 7$. Football for $£ 10$ a week in Glasgow was resistible.

After leaving school, Date had been a foundry worker, coal miner, and mechanic. In World War II he enlisted in the Australian Imperial Force but served for only five weeks (March-April 1942), being discharged as medically unfit when a piece of steel was found to be lodged in his right knee. Mining had kept him fit but when he took over the Queen's Arms Hotel at West Maitland in late 1947 the move proved problematic. Genial, gregarious, and fond of a drink himself, he began an annual battle with weight. At the same time, the demands of business were distracting. National selectors doubted his fitness and commitment, even if he was still regularly scoring goals. The rise of his young rival Frank Parsons notwithstanding, petty politics by selectors, ruffled by Date's larrikin manner, combined with interstate rivalries to ensure he was denied national selection between 1948 and 1950, including for the 1950 tour to South Africa. The unspoken ban haunted him and confounded contemporaries.
Having moved to the Ocean View Hotel at Dudley, Newcastle, in 1948, Date took over the Albion Hotel at Wickham in 1953. He had retired from football a number of times before finally finishing in 1954 . He retained his love of the game but also had other passions, particularly punting and boxing. The Albion drew a clientele that reflected Date himself, colourful and sporty. Anyone was welcomed but his working-class loyalties never wavered. In 1980 he retired from the Albion; fishing and swimming were favourite activities in the following years. He died on 11 August 1995 at Waratah, survived by his wife and two sons; he was cremated. His funeral at St Andrew's Anglican Church, Mayfield, attracted around 2,000 people. In 1999 he was an inaugural inductee into Australian soccer's national hall of fame. The legendary player Joe Marston rated his old friend as 'the best Australian player he ever played with, or against' (Cockerill 2012, Weekend Sport 10).

Allen, Peter. Reg Date: The Don Bradman of Football. Mosman, NSW: Allen Media Services, 2011; Brooks, Bob. 'Not Only a Soccer Hero, But Everyone's Mate.' Australian, 29 September 1995, 10; Cockerill, Michael. 'Tough as Old Boots and Now He's a Living Legend.' Sydney Morning Herald, 6 April 2012, Weekend Sport 10; Davidson, John. 'The Forgotten Story of ... Reg Date, the Don Bradman of Football in Australia.' Guardian (London), 3 April 2015. Accessed 30 October 2018. www.theguardian.com/football/blog/2015/ apr/02/the-forgotten-story-of-reg-date. Copy held on $A D B$ file; Grant, Sid, comp. Jack Pollard's Soccer Records. North Sydney: Jack Pollard, 1974.

Philip Mosely

\section{DAVIDSON, BRUCE ROBINSON}

(1924-1994), agricultural scientist and agricultural economist, was born on 8 May 1924 at Brighton, Victoria, son of William Hamilton Davidson, farmer, and his wife Kate Nina Wynne, née Game. Members of his father's family were pioneers of the Tambo Crossing area. Initially educated at Tambo Crossing primary and Bruthen State schools, Bruce attended Trinity Grammar School, Kew, Melbourne, from 1939 to 1941 . He obtained his Leaving certificate in December 1941, and became a student teacher.

Having enlisted in the Citizen Military Forces in May 1942, Davidson transferred to the Royal Australian Air Force on 30 October. He qualified as a wireless operator air gunner. 
While serving with No. 9 (Fleet Co-operation) Squadron from October 1943 to January 1945, he spent three months in New Guinea in late 1944. In January 1945 he was promoted to temporary warrant officer and on 1 October he was discharged from the RAAF.

After obtaining a diploma of agriculture from Dookie Agricultural College in 1948, Davidson attended the University of Melbourne (BAgSc, 1952; MAgSc, 1954). He married Mary Devonald Thomas, a Welsh farmer exchange student whom he had met during his studies, on 22 August 1953 in Melbourne. The couple moved to the United Kingdom and he studied agriculture at the University of London (PhD, 1957). In 1956 he published-with G. P. Wibberley-The Agricultural Significance of the Hills. Between 1957 and 1960 he lectured at Egerton Agricultural College in Kenya.

Returning to Australia, Davidson was a research officer with the Commonwealth Scientific and Industrial Research Organisation in Canberra from November 1960. He investigated north Australian agricultural development, but resigned early in 1963 when he felt he was being actively discouraged from publishing the results of that research, which were unfavourable to rural expansion schemes. Developing the north, both to encourage trade with Asia and to assist in settling what were seen as dangerously underpopulated areas, had become a widely supported national goal. Between February 1963 and March 1965 he was a temporary lecturer and a research fellow in agricultural economics at the University of Western Australia, where he continued his north Australian work. In the intense public debate over the Ord River Irrigation Area, he spoke against the scheme, in opposition to the Western Australian minister for the northwest, (Sir) Charles Court.

In March 1965 Davidson was appointed a lecturer in agricultural economics at the University of Sydney. Following Mary's death in 1964, on 18 June 1965 at the Congregational Church, Mosman, New South Wales, he married Sydney-born Dr Hilary Frances Purchase, an agricultural scientist with whom he collaborated professionally. He was promoted to senior lecturer in 1966 , and acted as head of department in 1968. His lectures were 'a delightful combination of intellectual rigours [sic] and iconoclasm delivered in an unorthodox style' (Walsh 1994, 13). A stimulating speaker, he was not afraid to challenge provocatively the status quo. In a 1966 address in Canberra, for instance, he called farmers on the Ord River 'Australia's highest paid pensioners' (Samuel $1966,3)$. He published many books, also quite often involving the expression of controversial views. His outspokenness may explain his failure to be promoted beyond senior lecturer. He retired in 1989.

Davidson's most important publication was The Northern Myth: A Study of the Physical and Economic Limits to Agricultural and Pastoral Development in Tropical Australia, published in three editions in 1965, 1966, and 1972. Extending his earlier criticisms of the Ord River scheme, the book argued that development of irrigated agriculture in northern Australia could not, on purely economic grounds, be justified. Although it attracted the ire of prominent proponents of north Australian economic development, it had a far-reaching impact. The senior Federal Labor minister Peter Walsh later described it as a 'devastating critique of tropical irrigated agriculture in general and of the proposed Ord River Dam in particular' (Walsh 1994, 13). Libby Robin, the environmental historian, wrote that it 'exposed at length the lack of economic sophistication in the scientific research into the "possible" (Robin 2007, 143). Other significant books were Australia Wet or Dry? The Physical and Economic Limits to the Expansion of Irrigation (1969) and European Farming in Australia: An Economic History of Australian Farming (1981). He also wrote The School in the Valley (1984), a history of the Tambo Crossing Primary School. In retirement he published papers on the economic history of Australian farming, and a book on legumes co-authored with his wife.

Davidson was one of Australia's most publicly influential agricultural economists. 'No one in our profession', three of his colleagues observed, 'could weave so compelling an argument from such a fund of facts' (Batterham, Mauldon, and Ockwell 1994, 121). Generous, persistent, and cheerful, he was sociable but argumentative. $\mathrm{He}_{s}$ loved the bush and hated war. Nominally he belonged to the Church of England. A short, thin man of fair complexion, he enjoyed drinking and smoking. Towards 
the end of his life he developed emphysema. He died of lung cancer on 22 March 1994 at Wahroonga, New South Wales, and was cremated; his wife, and the three daughters and two sons of his first marriage, survived him. One son, Brian, became an associate professor in the department of agriculture and food systems at the University of Melbourne. The University of Sydney established a prize for proficiency in natural resource economics in his name.

Batterham, Bob, Roger Mauldon, and Tony Ockwell, 'Bruce Robinson Davidson 1924-1994.' Australian Journal of Agricultural Economics 38, no. 1 (April 1994): 121-24; Batterham, Bob. Personal communication; Davidson, Brian. Personal communication; Gosford, Bob. 'Bruce Davidson and the Myth of a Northern Food Bowl.' The Northern Myth (blog), Crikey, 6 February 2014. blogs.crikey.com.au/northern/2014/02/06/ bruce-davidson-and-the-myth-of-a-northern-foodbowl. Copy held on $A D B$ file; National Archives of Australia. A3901, 5528375, B884, V500816; Robin, Libby. How a Continent Created a Nation. Sydney: UNSW Press, 2007; Samuel, Peter. 'Ord Farmers "Highly Paid Pensioners".' Canberra Times, 19 April 1966, 3; Walsh, Peter. 'Outspoken Critic of Ord Dam Project.' Australian, 6 April 1994, 13.

David Carment

\section{DAVIS, BEATRICE DELOITTE} (1909-1992), editor, was born on 28 January 1909 at Bendigo, Victoria, second of three children of Victorian-born Charles Herbert Davis [q.v.8], solicitor, and his Sydneyborn wife Emily Beatrice, née Deloitte. Her mother's family was related to the English Deloittes of international accounting fame. While her father was on active service during World War I, the family moved to Sydney to live with the Deloittes. After the war they stayed in Sydney, but by the time Beatrice was fourteen her adored father had died.

Davis was educated at Neutral Bay Public and North Sydney Girls High schools. With the help of a Teachers' College scholarship she graduated from the University of Sydney (BA, 1929), majoring in English and French with a sub-major in chemistry. She also studied at the New South Wales State Conservatorium of Music, and her piano later accompanied her wherever she lived, coming to dominate the living room of the art deco house at Folly Point, Cammeray, acquired after her marriage.
Having decided she was not suited to teaching, Davis found work as a secretary with the Medical Journal of Australia, where the editor, Mervyn Archdall, taught her his job. Through the $M J A$ she met Dr Frederick John Bridges, former medical superintendent of Royal Prince Alfred Hospital, who was divorced. They were married on 6 July 1937 at the registrar general's office in Sydney. He was twenty years her senior. Through Archdall she also met Walter Cousins, publishing director of Angus and Robertson [q.v.7, 11] Ltd (A\&R). In 1937 she was offered a job mainly reading proofs. Before long she was the first full-time editor at $A \& R$.

From her tiny office at the A\&R building (89 Castlereagh St), Davis soon became a significant figure in Sydney literary circles. In 1941, at Douglas Stewart's [q.v.18] suggestion, she inaugurated the annual Australian Poetry and Coast to Coast story anthologies. She hosted functions and meetings so that $A \& R$ became a meeting place for authors. As a member of the Sydney branch of the English Association, the Fellowship of Australian Writers of New South Wales and the Sydney PEN Club, she knew every Sydney writer of consequence. She reviewed books and manuscripts and under her influence $A \& R$ took over publication of the literary magazine Southerly. Her membership from 1957-together with her A\&R colleague, Colin Roderick - of the judging panel of the Miles Franklin [q.v.8] literary award provided her with a splendid perspective on Australian fiction, though in the sixteen years before she left the company, A\&R books won in only eight, three written by Thea Astley.

As important as Davis's knowledge of what was happening in Australian writing was her encouragement of the work of writers she admired or thought worthwhile. Her preference was for developing the literary tradition begun in the nineteenth century, as outlined in Miles Franklin's Laughter, Not for a Cage (1956). Increasingly she avoided the contemporary urban themes favoured by writers like Dymphna Cusack [q.v.17], Ruth Park, D'Arcy Niland [q.v.15], and Kylie Tennant [q.v.18], though the old bush tradition was fading and by 1983 she was wondering whether she had been right to accommodate Miles Franklin's enthusiasm for 'Brent of Bin Bin'. 
During her time at A\&R Davis was never paid as much as the men, who were also promoted over her, nor did she have any formal role in the firm's management. She had some income from her husband's estate, and therefore no reason to agitate for higher pay, but she was no feminist, preferring to flatter and cajole. She despised gender-neutral language. By the 1970s, however, her lack of status made her position vulnerable. Even so she had become a role model, especially for young women who aspired to work in publishing. Stylish, elegant, influential, and ubiquitous, she emphasised the need for an informed critical sense but advocated a self-effacing role for the editor as 'invisible mender' (McDonald $2012,13)$. These qualities she tried to instil in the editors she trained. In practice, however, she could be high-handed and judgemental. In her pursuit of literary quality she would ignore such matters as design, production costs, and marketing. Though under her influence A\&R had become synonymous with a particular kind of Australian literary publishing, in fact the firm's value was sustained largely by its non-literary, technical, trade, and general backlist, much of it popular Australiana. Its old-fashioned management style made it vulnerable in an aggressive market. After one serious takeover attempt from 1958 to 1959 , aimed at A\&R's valuable real estate as height restrictions on buildings in the Sydney central business district were lifted, there were others culminating with Gordon Barton's capture of the board in 1970 and his appointment of the youthful Richard Walsh to supervise and modernise the publishing department, which included Davis.

Davis was a heavy smoker, eventually developing emphysema, and never averse to a 'teeny piece' (Kent 2001, 175) of her favourite whisky, Vat 69, thus excusing all indiscretions. Shortly before Frederick Bridges died of tuberculosis in 1945, his old friend Edmund 'Dick' Jeune became her escort. He moved into a farmhouse she bought at Sackville on the Hawkesbury where, until he died in 1976, he grew oranges, raised chickens, and welcomed Davis at weekends. In 1960 she also met John Broadbent, a solicitor and former soldier, and began a relationship lasting thirty years. There were other admirers too. On paper she maintained intense friendships with several of her authors, most of them somewhat hapless, like Eve Langley [q.v.15] and Ernestine Hill [q.v.14], or Hal Porter [q.v.18], Kenneth Mackenzie [q.v.15], and Xavier Herbert [q.v.17]. Flirtatious and bossy, she was managing with the women, and more accommodating with the men, even taking them to bed after a few drinks- 'It's only sex, darling' (Kent 2001, 210). However, she was almost prudishly protective of the reputation of $A \& R$ when it came to lurid language or too much sex in books. Tom Hungerford had a manuscript shelved for years because it was too explicit, and when asked to tone down the language in another was offered an alphabetical list of problems, 'A is for arsehole, B is for balls', and so on (Kent 2001, 67). She clashed with Richard Walsh because he was keen to push the boundaries as he had done with $\mathrm{Oz}$ magazine and Nation Review, and to publish new writing, such as a lesbian novel by Kerryn Higgs and Dennis Altman's ground-breaking Homosexual: Oppression and Liberation. But, as well, her highly personal, even idiosyncratic, way of managing the editorial process was no longer suited to modern publishing. It was time-consuming and far from transparent.

When Davis (and several of her editors) were sacked by 'the boy publisher' in 1973 (Kent 2001, 268), there was consternation. Eighty-two written tributes were gathered and bound, and are deposited in the Mitchell [q.v.5] Library together with her papers. But she was soon offered other work, and chose to become Sydney editor for Thomas Nelson (Australia) Pty Ltd's expanding operation. Several of her authors followed her. 'Where Beatrice goes, I go too', Thea Astley declared (Astley, pers. comm.). Folly Point served as her office until changes at Nelson meant that by 1981 she was no longer needed. She continued freelancing, and serving as the last of the Franklin prize judges appointed by Miles personally. A fall in 1989 eventually drove her from Folly Point to a nursing home at Hunters Hill. Her judging of the 1992 Franklin prize was just finished when she died on 24 May at the home, two days before the winner was announced; she was cremated.

For her services to literature Davis was appointed MBE in 1967 and AM in 1981. The University of Sydney awarded her an honorary doctorate of letters in 1992. According to her biographer, Jacqueline Kent, her power was due to "her combination of high intelligence, 
critical acuity, wit and charm', and because 'A\&R was for a long time the only publishing company of any size in Australia'. Book marketing 'in the modern sense was in its infancy and editorial control was much greater' (Kent 2006, 181-82). Her style added greatly to the legend of $A \& R$, but notwithstanding the legend, developments she pioneered as an editor in Sydney were occurring concurrently elsewhere. As she became more influential, she was a restraining rather than a driving force in Australian publishing. The Beatrice Davis Editorial Fellowship was established in her honour.

Astley, Thea. Personal communication with author; Barker, Anthony. One of the First and One of the Finest: Beatrice Davis, Book Editor. Carlton, Vic.: The Society of Editors (Vic.) Inc., 1991; Kent, Jacqueline. A Certain Style: Beatrice Davis, A Literary Life. Ringwood, Vic.: Viking, 2001; Kent, Jacqueline. 'Case Study: Beatrice Davis.' In Paper Empires: A History of the Book in Australia 1946-2005, edited by Craig Munro and Robyn Sheahan-Bright, 177-82. St Lucia: University of Queensland Press, 2006; McDonald, Rowena. 'Beatrice Davis and "The Sacredness of the Printed Word".' Australian Literary Studies 27, nos. 3-4 (October-November 2012): 13-30; State Library of New South Wales. MLMSS 7638, Beatrice Davis papers, 1952-1989; Walsh, Richard. 'Case Study: The New A\&R.' In Paper Empires: A History of the Book in Australia 1946-2005, edited by Craig Munro and Robyn Sheahan-Bright, 57-63. St Lucia: University of Queensland Press, 2006.

Beverley Kingston

\section{DE LISLE, VISCOUNT WILLIAM} PHILIP (BILL) (1909-1991), governorgeneral, was born on 23 May 1909 at Chelsea, London, only son of William Sidney, barrister, mayor of Chelsea (1906-08), London County councillor (1922-34), and 5th Baron De L'Isle and Dudley, and his wife Winifred Agneta Yorke, née Bevan. Family ancestors included the courtier-poet Sir Philip Sidney and King William IV. Suffering from asthma in childhood, Bill did not attend boarding school until he entered Eton (1923-27). While at Magdalene College, Cambridge (BA, 1930; $\mathrm{MA}, 1935)$ he was commissioned in the Grenadier Guards reserve of officers (1929).

He qualified as a chartered accountant, was elected to Chelsea Borough Council in 1937 and was working at Barclays Bank's Pall Mall office at the outbreak of World War II.
Joining his regiment, he served in France before being evacuated from Dunkirk in May 1940. In a Church of England ceremony he married Jacqueline Corinne Yvonne Vereker, daughter of the 6th Viscount Gort, on 8 June at the Royal Military Chapel, Wellington Barracks, London. Returning to duty, he served in North Africa and Italy. At Anzio during the night of 7-8 February 1944 Major Sidney repeatedly led his men into action and inspired them with extraordinary acts of courage, despite suffering a serious wound. He was awarded the Victoria Cross.

Back in London, he transferred to the army reserve and in a by-election in October 1944 was returned unopposed as National Conservative member for Chelsea in the House of Commons. He was parliamentary secretary, ministry of pensions, in (Sir) Winston Churchill's government from May 1945. On his father's death the next month, De L'Isle succeeded to the barony and entered the House of Lords. In 1949 he opened his historic home, Penshurst Place, Tonbridge, Kent, to the public and for the rest of his life improved and restored it while delighting in showing visitors its beauties. He was secretary of state for air (1951-55) in Churchill's last government; on a visit to Australia with his wife in November 1955 he inspected the Long Range Weapons Establishment's testing ranges at Woomera, South Australia. Resigning from the air ministry the following month, he was created 1st Viscount De L'Isle of Penshurst in January 1956. He resumed his business career and became a director of several companies, including Lloyds Bank, and managing director of Schweppes (Home) Ltd.

Seeking a replacement for GovernorGeneral Lord Dunrossil [q.v.14] while visiting England in March 1961, Prime Minister (Sir) Robert Menzies [q.v.15], unable to 'think of an Australian who would be satisfactory', selected De L'Isle. Appointed GCMG in May, he reached Canberra with his family on 2 August and took office next day. Some 6 feet $(183 \mathrm{~cm})$ tall, affable, and active, His Excellency enjoyed the vice-regal trappings and travelled widely. He bought two cattle properties near Armidale, New South Wales. Lady De L'Isle died in Canberra on 16 November 1962. Her husband gifted a chime of bells cast in England to the Church of St John the Baptist, Canberra, in her memory. 
When De L'Isle welcomed Queen Elizabeth II to Australia on her second royal tour in February 1963, his daughter Catherine carried out the duties of hostess at Yarralumla. No political controversies occurred during his term. His decision in October 1963 to grant Menzies a premature dissolution of the House of Representatives evoked no criticism, though it led to separate Senate and House elections for a decade. This was the only occasion that the House has been dissolved prematurely without a defeat of the government in the House or to synchronise elections for both houses of parliament. In June 1964, resplendent in white dress uniform and plumed hat, His Excellency opened the new House of Assembly in Port Moresby, Territory of Papua and New Guinea. Due to his wife's illness and funeral, he had spent several months in England in 1962; he also took leave there from June to August 1964.

The last Englishman to be appointed Australian governor-general and the last (so far) to wear the uniform of office, De L'Isle relinquished his duties on 6 May 1965 and resumed his London business career. In 1968 he was appointed KG. At the British Embassy, Paris, on 24 March 1966 he had married Margaret Eldrydd Bailey, née Shoubridge, widow of the 3rd Baron Glanusk. Viscount De L'Isle died on 5 April 1991 at Penshurst Place, London, and was buried in the family vault. His wife and the son and four daughters of his first marriage survived him. His portrait by Clifton Pugh [q.v.18] is in the Parliament House art collection.

Australian Women's Weekly. 'New Bells for St. John's.' 1 July 1964, 3; National Archives of Australia, Personal Papers of Prime Minister Menzies, M2576/14, 1172484; Sydney Morning Herald. 'New Governor-General is Lord De L'Isle: V.C., Former U.K. Minister.' 11 April 1961, 1, 2, 4 \& 19, 'Warm Welcome For De L'Isles.' 3 August 1961, 10, 'Colour, Pomp as Lord De L'Isle Assumes Office.' 4 August 1961, 1, 'Lord De L'Isle "Proud to Step on Aust.Stage”.' 5 May 1965, 1, 'He Saw Every Corner of Aust.' 5 May 1965, 6, 'Hero We Were Quick to Salute.' 8 April 1991, 6; The Times (London). 'Two VCs Valour in Anzio Beach-Head.' 31 March 1944, 4, 'Chelsea’s V.C. M.P.' 12 October 1944, 4, 'Called by the "Fates" to Play Many Roles.' 11 April 1961, 7, 'Viscount De L'Isle.' 8 April 1991, 16, 'Viscount De L'Isle.' 30 April 1991, 16; Woman's Day. 'A Governor-General Returns to Australia, 20 Years On.' 22 April 1985, 52.

Chris Cunneen
DEICKE, ROY (1929-1995), sugar technologist and sugar industry executive, was born on 3 January 1929 at Herberton, North Queensland, third child of Queensland-born parents Charles Alfred Deicke, mechanic, and his wife May, née Pawsey. Roy attended Herberton State School (1934-41) and, in Brisbane, the State Industrial High (1943-44) and State High (1945-46) schools. At the University of Queensland (BScApp, 1953; DipSugTech, 1956), he studied industrial chemistry and sugar technology and taught (1952-54), as a demonstrator and then a temporary lecturer, in the department of chemistry. In 1955 he was appointed to the mill technology division of the Bureau of Sugar Experiment Stations at Bundaberg, beginning an association with the city that would span almost four decades. On 11 February 1956 at St Agatha's Catholic Church, Clayfield, Brisbane, he married Ellen Agnes (Nell) McKeone, a nurse.

In 1960 Deicke moved to the private sector, joining the Fairymead Sugar Co. Ltd at Bundaberg. His abilities were quickly recognised with the dual appointment of research officer and assistant general mill manager in 1961, and promotion to general manager in 1963. Under his guidance the company rapidly expanded, resulting in the acquisition of Gibson [q.v.4] \& Howes Ltd, sugar millers, and the formation of the Bundaberg Sugar Co. Ltd in 1972, with Deicke as group chief executive. Three years later he played a pivotal role in Bundaberg Sugar's takeover of the Millaquin Sugar Co. Ltd. The merger saw Deicke elevated to managing director (1976-87), followed by his appointments as deputy chairman (1981) and chairman (1986) of the company's board of directors.

Control of Millaquin Sugar also brought its subsidiary, Bundaberg Distilling Co. Ltd, into the Bundaberg Sugar fold. Deicke took an active role in overhauling the distillery's operations and promoting a more sophisticated image of its products, particularly its premium brand, Bundaberg Rum. Among his numerous improvements was the installation of new bottling machinery. He forged a crucial partnership with the Distillers Co. Ltd, Edinburgh, then the world's largest spirit company, to substantially increase marketing outlets for the Bundaberg distillery's products. 
In 1974 Deicke had been appointed to the Bundaberg Bulk Sugar Terminal Organisation, and in 1978 he was elected chairman of directors of Bundeng Ltd, a major Bundaberg engineering firm. These connections reinforced his powerful advocacy for continuing technological advances within the sugar industry. He also served as a director (1971-88) and chairman (1975-88) of the Proprietary Sugar Millers' Association; a member (1973-88) and chairman (197588) of the Sugar Research Institute; vicepresident of the Australian Sugar Producers' Association; and a member (1957-88), president (1971-72), and life member (1989) of the Queensland (Australian from 1979) Society of Sugar Cane Technologists. For his contribution to the Australian sugar industry, he was appointed CMG (1982).

A 'big, shambling man', with a penchant for large American cars, Deicke had an affable personality that masked a steely resolve to successfully accomplish his aims (Fagan 1995, 15). A later Bundaberg Sugar chief executive, Geoff Mitchell, remarked: 'If Roy wanted something, he got it' (Fagan 1995, 15). In an industry subject to climatic and economic fluctuations, albeit closely regulated, Deicke's strategy was designed to ensure a measure of security for sugar processors through largescale operations. At the pinnacle of his career, however, a serious slump in the world price of the commodity and uncertainty about the industry's future profitability convinced shareholders in Bundaberg Sugar to hand over control to the British-based conglomerate Tate \& Lyle Ltd in 1991, a move which Deicke vigorously opposed. His disappointment at failing to convince a majority to hold firm was reflected in his decision to resign that year from the company to which he had dedicated three decades of his life.

Deicke maintained a close relationship with his former colleagues, despite being based in Brisbane from the late 1980s. His continuing interest in business affairs and technology culminated in the chairmanship of both the Queensland Industry Development Corporation (1990-95), largely targeting the rural sector; and the University of Queensland Foundation (1985-95), which channelled corporate funding into that institution's research programs. The university awarded him an honorary doctorate of engineering
(1990). He had been elected a fellow of the Australian Academy of Technological Sciences (and Engineering) in 1984.

Although suffering from hypertension and arterial disease, Deicke cared for his wife at home, as her condition steadily deteriorated from the effects of Alzheimer's disease. Only four months after her death in 1994, he died of a stroke on 16 January 1995 at the Wesley Private Hospital, Auchenflower, and was buried in the Pinnaroo lawn cemetery, Aspley. His son survived him.

Fagan, David. 'The Man Who “Made” Bundy.' Australian, 31 January 1995, 15; Kerr, John. Southern Sugar Saga: A History of the Sugar Industry in the Bundaberg District. Bundaberg: Bundaberg Sugar Co. Ltd, 1983; Rehbein, Rod. 'Tributes Flow for Industry Giant.' News-Mail (Bundaberg), 17 January 1995, 4.

MurRay Johnson

DEKYVERE, NOLA LAIRD (19041991), charity worker and socialite, and DEKYVERE, MARCEL FRANCE (19131997), wool broker, were wife and husband. Nola was born on 1 July 1904 in Sydney, only child of Walter Laird Kerr, jeweller, and his wife Florence May, née Dive, both Sydney born. She was educated at St Catherine's Church of England Girls' School, Waverley, and Ascham School, Edgecliff, where she was known as 'one of the beauties' (Sydney Morning Herald 1991, 4). While still at school, she was mentioned in the social pages of the Sydney press and would frequently feature there over the next seven decades. On 6 March 1928 at St Stephen's Presbyterian Church, Sydney, she married Alan William McGregor, a partner, with his brothers (Sir) James Robert [q.v.15] and Harold Waddell McGregor [q.v.15], in the family wool-broking firm, J. W. McGregor \& Co. Alan died suddenly, aged forty-two, on 1 December 1938. The following year, the widowed and childless Mrs McGregor, wearing black, resumed the social and charitable round. On 19 October 1940 at St Mary's Cathedral, Sydney, she married Marcel Dekyvere; they were to remain childless.

Marcel was born on 27 November 1914 in Adelaide, younger son of Victor Adolphe Dekyvere, a French-born wool buyer, and his New Caledonian-born wife Beatrice Mabel, née Laurie. After the family moved to Sydney between 1915 and 1916, Marcel was 
educated by the Jesuits at St Aloysius College, Milsons Point, and later at St Ignatius College, Riverview. He took part in the Head of the River contest in 1932 as a member of the St Ignatius College eight. On leaving school, he joined his father and elder brother, also Victor, in the family business.

Early in World War II Victor Dekyvere junior was called up by the French government to serve in Indochina (Vietnam). Marcel paid for flying lessons and, in the face of French government opposition, enlisted in the Royal Australian Air Force on 27 May 1940. Qualifying as a pilot, he was commissioned in January 1941 and sent to Britain the next month. He flew briefly with No. 257 Squadron, Royal Air Force (July-August), and No. 129 Squadron, RAF (August-October), before joining the Air-Sea Rescue Flight at Hawkinge, a component of No. 277 Squadron, RAF, from December. Piloting Spitfires, for spotting downed aircrew, and Walrus flying boats, for rescuing them, he saved many lives and showed 'outstanding leadership and initiative as a flight commander' (NAA A9300); he was awarded the Distinguished Flying Cross. In November 1943 he was posted from the squadron and ordered back to Australia. From April 1944 he was an air-sea rescue staff officer at RAAF Headquarters, Melbourne, his duties requiring extensive travel throughout the South-West Pacific Area. He was promoted to acting squadron leader in November. His RAAF appointment terminated on 7 March 1946.

From 1951 to 1954 Marcel was an honorary aide-de-camp to the governor of New South Wales, Sir John Northcott [q.v.15]. His role included serving Queen Elizabeth II and Prince Philip during their tour of Australia in March-April 1954. The prince must have forgiven, or forgotten, their first meeting in Sydney during the war when, as a young sailor, he had been introduced to the Dekyveres as 'Philip of Greece' and Marcel had responded 'and I am Marcel of France' (Lawson 1990, 202).

The international demand for Australian wool post-World War II brought prosperity to the family business. When sales fell after the Korean War, Marcel sought new markets, travelling often and widely. He pioneered exports to Poland, Czechoslovakia, Albania, China, Pakistan, and India. Nola travelled with him. The women's pages of Sydney's papers published reports of their race meetings, famous encounters, dress shows, lunches, dinners, and shopping. Marcel was constantly at Nola's side, but he preferred her to shine. Nearly a decade younger than his wife, 6 feet $(183 \mathrm{~cm})$ tall, with an olive complexion and matinee-idol looks, he was an excellent dancer and for years the Dekyveres regularly occupied a banquette near the dance floor at the fashionable Prince's restaurant in Martin Place.

Nola's charity work began in the 1930s. Historically, this role had been the preserve of the daughters and wives of pastoralists, plutocrats, and knighted professionals but she took her place among such women with good humour, kindness, flair, and evident ability. She was an enthusiastic member of the Peter Pan Committee, which raised funds for a free kindergarten in Sydney; however, her main charitable focus was the blind. In 1936 she helped to form the White (later Black and White) Ball Committee, which held an annual ball for the Royal Sydney Industrial Blind Institute (later the Royal Blind Society), serving as the committee's president from 1952 to 1970 . 'Charmingly autocratic' (Sydney Morning Herald 1991, 4), she had a fondness for being in charge and a genius for fundraising that accounted for her long reign. She also served as an executive member of the Red Cross Special Appeals Committee during World War II, president (1959-80) of the Ladies Committee of the Sydney Opera House, and president and patron of the Royal Prince Alfred King George $\mathrm{V}$ Appeals Committee among other charity work. Appointed MBE in 1958, and elevated to $\mathrm{CBE}$ in 1972 in recognition of service to the visually impaired, she was dubbed 'Sydney's queen of charity' (Hill 1987, 8).

In May 1962 (Sir) Frank Packer [q.v.15] had engaged Nola to write a weekly column for his Sunday Telegraph to increase the paper's readership on Sydney's North Shore. Over the next eight-and-a-half years 'My Week' gave readers insight into the social life of Sydney's elites, Nola's encounters with prominent visitors to the city, her church, and the antics of her two poodles, Gigi and Jean. This was the only job for which Nola was ever paid. She generally avoided controversy, except for a disagreement with Patrick White [q.v.18] 
in July 1962 over his play The Ham Funeral. Feeling sorry for the playwright's mother, whom she knew, Dekyvere lamented: 'I couldn't bring myself to like Mr White's strange play. In fact I hated it. To my mind, the play was in very bad taste, with its sordidness and bad language' (1962, 51). Meeting each other at a gallery later that week, White refused to be photographed with her. In his next play, The Season at Sarsaparilla, he named a character after her, Nola Boyce, the wife of a sanitary worker.

Suffering from Alzheimer's disease, Nola died on 13 November 1991 at Lulworth House, Elizabeth Bay, a nursing home that, ironically, had once been the childhood home of Patrick White. Marcel, who retired from full-time work in the 1980s, continued to surf and play golf until his death at Darlinghurst on 2 February 1997, the result of a car accident.

Dekyvere, Nola. 'My Week.' Sunday Telegraph, 15 July 1962, 51; Hill, Robin. 'When Charity Began at the Trocadero.' Sydney Morning Herald, 14 February 1987, 8; Lawson, V. Connie Sweetheart: The Story of Connie Robertson. Port Melbourne: Heinemann, 1990; McNicoll, D. D. 'Broker Loved by High Society.' Australian, 14 February 1997, 17; National Archives of Australia. A9300, DEKYVERE M. F; Sydney Morning Herald. 'Helping Others a Life's Work for Charity Queen.' 14 November 1991, 4.

Mark McGinness

DELACOMBE, SIR ROHAN (19061991), governor, was born on 25 October 1906 at St Julians, Malta, second child and only son of Addis Delacombe, army pay officer, and his wife Emma Louise Mary, née Leland. The Delacombe family seat was Shrewton Manor, near Salisbury, Wiltshire, and several generations of Delacombes had served in the armed forces. Educated at Harrow School and the Royal Military College, Sandhurst, Rohan acquired the lifelong nickname of 'Jumbo' because, as he put it, 'I was a very large small boy' (Paterson 2001, 525). Commissioned in the Royal Scots (The Royal Regiment) in 1926, he served in Egypt, China, and India.

Posted to Palestine in 1938, Delacombe was wounded during a revolt by Palestinian nationalists. He was mentioned in despatches and appointed MBE in 1939. Early in World War II, from April to May 1940 he took part in the unsuccessful Allied campaign in Norway. An appointment followed as secondin-command of the $7 \mathrm{th} / 9$ th Battalion of the Royal Scots. On 15 February 1941 at St Hilda's Parish Church, Egton, Yorkshire, he married Eleanor Joyce Foster, whose parents resided at Egton Manor. In April 1943 he was appointed commanding officer of the 8 th Battalion with the rank of lieutenant colonel. During the Normandy campaign, he was awarded the Distinguished Service Order (an honour also won by his father) for his leadership during a sustained German counter-attack at Haut du Bosq on 28-29 June 1944, when 'his cool methodical manner and utter disregard for danger' kept his battalion intact (NA WO $373 / 49 / 14)$. The next month he was severely wounded and evacuated to England. He commanded the 2 nd Battalion in Italy from December 1944 to February 1945, and then in Palestine for the remainder of the war.

Delacombe served in Malaya (1945-49), then in West Germany, where he was promoted to CBE (1951) for his outstanding performance as colonel in charge of training the British Army of the Rhine (1949-50), and where he commanded the 5th Infantry Brigade (195053). Serving as deputy military secretary of the War Office (1953-55), he was then placed in command of the 52nd (Lowland) Division in Glasgow (1955-58). He was promoted to major general in 1956 and appointed CB in 1957.

In 1959 Delacombe returned to Germany to take up the role of commandant of the British sector in West Berlin. At a time when Cold War flashpoints in the divided city were frequent, his military post required diplomatic capacity. His most severe test came in August 1961, with the construction of the Berlin Wall and consequent tensions. When the border was first closed, Delacombe made the crucial and correct judgement that nearby Russian troops were moving to prevent people crossing the border, not preparing to attack his positions. Elevated to KBE in 1961, he retired from the army the next year.

On 8 May 1963 Delacombe was sworn in as governor of Victoria. More than 6 feet $(183 \mathrm{~cm})$ tall, round faced and moustached, he possessed an air of calm amiability and was thought to be 'a decent and kindly man' (Richards 2002, 327). His public image obscured the intensity of his interest 
in local events and politics, evident in his detailed and lively despatches to Britain. In 1969 he drafted a memo expressing dismay that the government had announced the appointment of the Victorian agent-general without consulting him; he felt that this action brought the office of governor-in-council into disrepute, 'as a mere rubber stamp or cipher for the decisions of the Cabinet' (PROV VPRS 7582). In 1974 he was angered by an 'undemocratic' (PROV VPRS 14578) directive from Gough Whitlam's Federal Labor government requiring 'Advance Australia Fair' to be played at Anzac Day ceremonies instead of 'God Save the Queen'. At the ceremonies attended by Delacombe, 'Advance Australia Fair' was not heard.

Delacombe largely avoided controversy, but in 1967 he was drawn into the bitter public debate preceding the execution of Ronald Ryan [q.v.16]. Some anti-hanging campaigners hoped that the governor would intervene and exercise his prerogative of mercy; Delacombe took the view that he was bound to act on the advice of his ministers. When the full executive council was convened to approve the order for execution, he 'carefully went around the table' to ensure that all those present agreed with the order (Richards 2002, 283). In 1971 Victoria’s Opposition leader, Clyde Holding, criticised him for his presence at a rugby union match involving the visiting South African team, and for publicly supporting the actions of police against anti-apartheid demonstrators during the game.

While serving as governor of Victoria, Delacombe was appointed KCMG (1964) and KCVO (1970), and he received honorary degrees from the University of Melbourne (LLD, 1967) and Monash University (LLD, 1971). He acted as administrator of the Commonwealth of Australia on four occasions. Retiring from the governorship in May 1974, Delacombe was the last of his type as governor of Victoria, a well-bred Briton with a military background. The State's first locally born governor, Sir Henry Winneke [q.v.18], succeeded him. Delacombe returned to his home at Shrewton Manor, where he died on 10 November 1991, survived by his wife, son, and daughter.

Lahey, John. 'A Gentle and Respected Governor.' Age (Melbourne), 13 November 1991, 21; National Archives (UK). WO 373/49/14; National Archives
(UK). WO 373/158/226; Paterson, Robert H. Pontius Pilate's Bodyguard: A History of the First or the Royal Regiment of Foot, The Royal Scots (The Royal Regiment). Vol. 2, 1919-2000. Edinburgh: Royal Scots History Committee, 2001; Public Records Office of Victoria. VPRS 14578, VPRS 7582, P0001/4; Richards, Mike. The Hanged Man: The Life \& Death of Ronald Ryan. Carlton North, Vic.: Scribe Publications, 2002; Taylor, Frederick. The Berlin Wall: 13 August 1961-9 November 1989. London: Bloomsbury, 2006; Times (London). 'Major-General Sir Rohan Delacombe.' 12 November 1991, 16.

Geoff Browne

DEROBURT, HAMMER (1922-1992), head chief and president of the Republic of Nauru, was born on 25 September 1922 in the Territory of Nauru, son of DeRoburt and Eidumunang. His maternal grandfather, Daimon, was head chief of Nauru (1920-30). In the aftermath of World War I, a League of Nations Mandate was granted to the United Kingdom, with Australia and New Zealand, sharing administrative control over Nauru as the British Phosphate Commissioners (BPC). Under the mandate the BPC was committed to managing the island's affairs, with Australia appointing a chief administrator. The BPC also took responsibility for managing phosphate mining. These dual responsibilities would sit uneasily beside the commissioners' financial interests in phosphate deposits on the island.

Raised in the district of Boe, DeRoburt was educated at the Nauru Boys' Secondary School. In the late 1930s he and several other boys were sponsored by Harold Hurst, an Australian boy scouts commissioner, to attend Geelong Junior Technical School in Victoria. While Hurst aimed to equip his charges for leadership roles in their homeland, critics believed his plan produced a group of 'overeducated and over-Europeanised' youths (R.W.R. 1941, 25). Returning to Nauru, DeRoburt took a position as a teacher (194042) until he was exiled to Truk (Chuuk) along with 1,200 other Nauruans by the Japanese military occupation (1943-45) of the island during World War II. He was among the fewer than 800 to survive. They returned to find Nauru devastated and polluted by the Japanese occupying force, and the mine destroyed by Allied bombing. Rebuilding the nation was a high priority for survivors including 
DeRoburt and the Nauru Local Government Council (NLGC) that would be formed in 1955 to administer their affairs.

From 1947 phosphate mining and administrative BPC governance was resumed under a United Nations (UN) Trusteeship. DeRoburt returned to education, taking on liaison and then teaching roles. On 19 August 1950 he married Lukale Rowena Harris, a Marshallese, at the London Missionary Society church, Orro. In 1953, as chairman of the Nauruan Workers' Organisation, he led a successful strike for reduced hours and a minimum wage for Nauruan families. Two years later he was elected to the NLGC and was made head chief.

DeRoburt was the architect of the Nauruan push for independence and control of the phosphate mine. He led councillors seeking to regain control of their people, their affairs, and their island environment. He also headed agitation for the rehabilitation of mined-out areas of Topside (the island's central plateau), while seeking to increase the returns Nauruans received from the BPC's sale of phosphate. As head chief and chair of the NLGC, he represented community demands to UN visiting missions (1956, 1959, 1962, and 1965) and to Australian administrators.

In 1964 DeRoburt and the NLGC rejected Australia's offer to relocate Nauruans to Curtis Island, off the Queensland coast, observing that his people had a deep cultural commitment to their island, despite the damage caused by mining. He continued to express Nauruan concerns to UN visiting missions, urging the trusteeship council to support moves towards Nauruan sovereignty. He employed lawyers, academics, publicists, and others to present Nauru's economic and politico-cultural position to the trusteeship council, BPC, Australian administrators, the press, and others. On 31 January 1968 Nauru was granted independence with DeRoburt elected as the first president. As part of the terms of the independence settlement the republic purchased the phosphate mine from the BPC for AU\$21 million and established the Nauru Phosphate Corporation (NPC) to continue mining. The country formally became the Republic of Nauru with DeRoburt re-elected intermittently as president (1968-76, 1978-86, 1986-89) until his death in 1992 .
Having achieved independence and control of the phosphate mine, DeRoburt reinstituted urgent negotiations for rehabilitation of worked-out lands. With phosphate deposits expected to be exhausted by 1995 , the NPC continued mining, while seeking outside guidance on investments, including a fleet of ships; their own airline, Air Nauru; and Nauru House, a high-rise building in Melbourne. Since the 1970s Nauruans had been urging the NPC to sell the remaining phosphate at true market rates in order to maintain the country's economy. In the 1980s, as economic conditions worsened, political opponents criticised his excessive spending and authoritarian approach to governance, but supported the urgent need to rehabilitate the worked-out mine areas.

For his beloved homeland DeRoburt pursued the matter of rehabilitation that former head chief Timothy Detudamo and other Nauruan leaders had long posed to the BPC and Australia as administering authority. The BPC's interests in mining profits, DeRoburt contended, conflicted with its obligations to the Nauruan community who were treated as secondary citizens on their own island and less important than migrants involved in the mine's operations. He also argued that the land at Topside, made inaccessible and unusable by mining, was vital to support the future needs of Nauru's expanding population. In 1989 DeRoburt instituted legal proceedings against Australia in the International Court of Justice in The Hague for compensation for environmental damages caused by mining. Although ill, he travelled with Nauru's legal advisors to address the court in November 1991. The parties settled in September 1993 before a determination by the court, Australia paying Nauru AU\$107 million.

Hardworking, charismatic, and softly spoken, DeRoburt was also a tough negotiator with a quick temper. Appointed $\mathrm{OBE}$ in 1966, he was elevated to an honorary GCMG in 1982. He represented Nauru at meetings of the South Pacific Forum and other regional organisations, as well as on the world stage. Chancellor (1974-76) of the University of the South Pacific, Fiji, he was accorded an honorary doctorate at the end of his term. As a youth he played Australian Rules football, but in later years listed 'resting' as his only recreational activity. He was a member 
of the Congregational Church and served as a deacon for Boe district. Predeceased by his wife and survived by their daughter, he died on 15 July 1992 while in Melbourne for medical treatment. He was accorded a state funeral, before being buried in Boe cemetery, Nauru.

National Archives of Australia. A463, 1988/1534.; Pollock, Nancy J. Nauru Bibliography. Wellington, NZ: Department of Anthropology, Victoria University of Wellington, 1994; Pollock, Nancy J. 'Nauru Phosphate History and the Resource Curse Narrative.' Journal de la Société des Océanistes, no. 138-39 (2014): 107-19; R.W.R. 'Too Much Geelong.' Pacific Islands Monthly, December 1941, 25; Viviani, Nancy. Nauru: Phosphate and Political Progress. Canberra: Australian National University Press, 1970; Weeramantry, Christopher. Nauru: Environmental Damage under International Trusteeship. Melbourne: Oxford University Press, 1992; Williams, Maslyn, and Barrie MacDonald. The Phosphateers: A History of the British Phosphate Commissioners and the Christmas Island Phosphate Commission. Carlton, Vic.: Melbourne University Press, 1985.

Nancy Pollock

DEXTER, DAVID ST ALBAN (19171992), army officer, historian, public servant, and university administrator, was born on 8 January 1917 at St Albans, Hertfordshire, England, the second of five sons and one daughter of English-born Walter Ernest Dexter [q.v.8], Church of England chaplain, and his Victorian-born wife Dora Stirling, née Roadknight. His father, a much-loved senior chaplain in the Australian Imperial Force (AIF), returned to Australia with his family in 1920 and his appointment was terminated. David lived at Kilsyth, Victoria, until 1923 when his father failed on his soldier-settler block, and then in clergy houses at Romsey, Lara, and West Footscray.

Educated at Geelong Grammar School (1930-35), Dexter accepted an appointment as a student teacher at Grimwade House, Melbourne Church of England Grammar School. He studied history at the University of Melbourne (BA Hons, 1940). On 8 October 1940 he enlisted in the AIF and in March the following year volunteered for commando training. Commissioned as a lieutenant in July, he was posted to the 2nd Independent Company (later 2/2nd Commando Squadron). British specialists rigorously trained him, and about 270 other recruits, in secret on
Wilsons Promontory. He was impressed by the concentrated nature of the instruction, which emphasised mobility, initiative, and speed.

The novice company arrived in Portuguese Timor (Timor-Leste) in December 1941 and then spent a year waging guerrilla warfare against the Japanese. A short, strongly built man, Dexter revelled in the bush life and independence. With the cooperation of the local people, ingenuity, and some luck, the company confused and harried much larger Japanese forces until their position became too dangerous; those who survived were evacuated to Darwin. Dexter was mentioned in despatches.

From June 1943 the company fought in New Guinea. During an operation in Japanese-held territory in the Ramu Valley in September, Dexter, now a captain, suffered five bullet wounds. He returned to Australia in March 1944, having been mentioned in despatches a second time. Between April and June 1945 he served with his squadron in New Britain. Promoted to major in June, he commanded the 2/4th Commando Squadron on Tarakan Island, Borneo, from September. His AIF appointment was terminated in Australia on 16 January 1946. He remained proud of the $2 / 2 \mathrm{nd}$, describing it as 'a pretty good unit, something quite remarkable, there hadn't been anything like it in Australian military history' (Dexter 1976). There were only twelve such Australian squadrons formed during World War II.

On 29 September 1944 at St Mark's Church, Camberwell, Melbourne, where his father was the minister, Dexter had married Freda Doris Irene Harper, a teacher. Reluctant to resume a career in education, in 1946 he joined the Department of External Affairs in Canberra and worked closely with the minister, H. V. Evatt [q.v.14], with whom he attended the second (1947) and third (1948) sessions of the General Assembly of the United Nations Organization. He admired Evatt's 'vast intellect', describing his time with him as 'that of bag carrier' (Cleary 2010, 330). In 1955 he headed the foreign aid branch of the department, working under a new minister, Richard (Baron) Casey [q.v.13]. Dexter was involved in the Colombo Plan and with formulating systems of foreign aid associated with the Southeast Asia Treaty Organization and the UNO. He attended 
a number of international conferences on aid, and in 1959 was appointed a counsellor to the Australian High Commission in India.

In 1946 Dexter had accepted a commission from Gavin Long [q.v.15], Australia's second official war historian, to write volume six of Australia's official history of World War II. In doing this he consciously adopted the method of the first official historian, Charles Bean [q.v.7], when writing his own official history, by gathering all his material into six 'master diaries'. Much of his writing was undertaken while he served as first secretary of the Australian High Commission in Ceylon (1952-55). He completed his lengthy manuscript in 1959 and the book, The New Guinea Offensives, appeared in 1961. It was warmly reviewed as 'a splendid readable and authoritative account' (Mackie and Ross 1992).

Appointed secretary of the Australian Universities Commission in 1960 on the urging of (Sir) John Bunting [q.v.], he relished his new opportunities. Sir Leslie Martin [q.v.18] chaired the commission and had the ear of Prime Minister (Sir) Robert Menzies [q.v.15]. Dexter found that 'any recommendations you made were bound to go through' (Dexter 1976). He wrote much of the commission's findings on Australian universities (the Martin Report). Resigning from the commission in 1967, he was recruited by The Australian National University (ANU) as registrar (property and plans) where he had responsibility for development of the grounds and buildings. Successful completion of numerous projects has been attributed to his 'sensitivity to people's needs and aspirations, combined with huge administrative competence, a card index mind, close attention to detail, and Puckish energy' (Mackie and Ross 1992, 11).

Dexter retired in May 1978 on medical grounds. He retained great respect for the people of South-East Asia, most notably the Timorese, for whom he felt a special affinity. He was also a regular researcher at the Australian War Memorial, to which he had donated his father's important letters and diaries. His book, The ANU Campus, a history of the ANU site, was published in 1991. Survived by his wife and five children (one son had predeceased him), he died at home in Canberra on 15 March 1992 and was cremated. A generous and gregarious man with many friends, his first and lasting love was for Freda and their children. He had a wide interest in politics and respected politicians and parliament.

Australian War Memorial. PR000249, David Dexter Papers; Cleary, Paul. The Men Who Came Out of the Ground: A Gripping Account of Australia's First Commando Campaign: Timor 1942. Sydney: Hachette Australia, 2010; Dexter, David. Interview by Hazel de Berg, 26 July 1967. Transcript. Hazel de Berg Collection. National Library of Australia; Dexter, David. Interview by Mel Pratt, 25 August 21 September 1976. Transcript. National Library of Australia; Dexter, David. The New Guinea Offensives. Canberra: Australian War Memorial, 1961; Dexter, David Jnr, Personal communication; Doig, Colin D. A History of the 2nd Independent Company and 2/2 Commando Squadron. Carlisle, WA: Hesperian Press, 2009; Funeral Oration: David Saint Alban Dexter. Unpublished manuscript, 19 March 1992; Mackie, J.A.C., and I.G. Ross. 'David St Alban Dexter.' ANU Reporter, 24 June 1992, 11; National Archives of Australia. B883, VX38890.

Michael McKernan

\section{DIBDEN, WILLIAM ANDREW} (BILL) (1914-1993), psychiatrist, was born on 22 March 1914 in Sydney, elder son of Frederick Samuel Dibden, printer's clerk, and his wife Ann, née Andrew. When Bill was eleven the family moved to Adelaide; he attended Prince Alfred College, where he excelled scholastically and participated in debating, cadets, and tennis. He became school captain in 1932. Having won a government bursary, in 1933 he enrolled in medicine at the University of Adelaide (MBBS, 1939). His studies were interrupted in 1934 when he was diagnosed with pulmonary tuberculosis; the illness precluded an application for a Rhodes scholarship, to which he aspired. In later years he was convinced that his experience as a patient during the long road to recovery left him with a heightened empathy for the weak and dependent.

Being considered unfit for active service in World War II, Dibden entered general practice in 1940 at Murray Bridge. On 20 July at St John's Church, Adelaide, he married Shirley Newsome Barton, who later championed the cause of children with specific learning difficulties. On 1 October 1941 he began full-time service as a captain in the Citizen Military Forces. He initially performed general 
medical duties at Woodside. In November he attended a twelve-week course in neurology and psychiatry in Melbourne, after which he was deployed as the psychiatrist at the 105th Australian Military Hospital, Adelaide.

On his discharge in March 1943 Dibden worked at Parkside Mental Hospital. He also established a psychiatric outpatient department at the Repatriation General Hospital, Keswick, in June the same year, and in 1945 he relieved as administrator at Enfield Receiving House, gaining his first experience of running a hospital. The following year he entered private practice as a psychiatrist and was a founding member of the Australasian Association of Psychiatrists (AAP). Seeking further training, he studied at the University of Melbourne (DPM, 1948) and the next year he took his family to England, where he studied at the Maudsley Hospital in London under (Sir) Aubrey Lewis [q.v.15]. There he came to appreciate that the complexities of mental disorder made diagnosis 'difficult and treatment uncertain ... causation complex and solutions rarely simple' (Dibden n.d., 75-76).

Returning to Adelaide in 1951 Dibden resumed private practice, as well as taking on honorary roles (later paid) at the Adelaide Children's Hospital. In 1954 he was chairman of a standing committee of the South Australian Council of Social Service on Mental Health. The South Australian Association for Mental Health was formed in 1956 to raise public awareness of the plight of the mentally ill, and to improve training for professionals. Strongly supporting the association's emphasis on mental health over mental illness, and prevention over treatment, he became executive chairman, and later president (1956-66). The association successfully launched an appeal in 1960 to establish a chair in mental health at the University of Adelaide; the first professor was appointed two years later.

The AAP was reformed as the Australian and New Zealand College of Psychiatrists in 1964, and in 1965 and 1966 Dibden was president. In his presidential address he noted the change that was underway in psychiatry; 'the walls have been lowered round our hospitals and the doors opened without public protest' (Dibden 1967, 13). He was appointed director of Mental Health Services on 7 December 1967.
During 1975 Dibden chaired a ministerial committee to review the existing mental health legislation for the State, and was actively involved in its revision. A new Mental Health Act was assented to on 12 May 1977. It included provision for a Guardianship Board, and a Medical Review Tribunal to safeguard the interests of patients and allow external scrutiny of medical decisions. Becoming director-general of medical services later that year, he considered his greatest administrative achievement to be 'an education programme for psychiatrists in training and the evolution of a new mental health act' (Dibden n.d., 159). He was appointed AO in 1978. After retiring in March 1979 he wrote a biographical history of psychiatry in South Australia. His empathy, energy, warmth, and integrity endeared him to many, and enabled him to achieve groundbreaking changes in mental health, to advance the rights of the mentally ill, and to foster significant improvements in psychiatric training. Survived by his wife, four daughters, and son, he died on 17 October 1993 at his home in Adelaide, and was cremated.

Dibden, William Andrew. 'In the Looking Glass.' Australian and New Zealand Journal of Psychiatry 1 (1967): 7-13; Dibden, William Andrew. 'A Biography of Psychiatry.' Unpublished manuscript. University of Adelaide Library. Accessed 30 March 2017. digital.library.adelaide. edu.au/dspace/bitstream/2440/15076/46/dibden_ fin.pdf. Excerpts held on $A D B$ file; Forbes, Ian L. D. From Colonial Surgeon to Health Commission: The Government Provision of Health Services in South Australia, 1836-1995. Myrtle Bank, SA: Ian L. D. Forbes, 1996; Holt, Averil G. Hillcrest Hospital: The First Fifty Years. Victoria: The Hillcrest Hospital Heritage Committee, 1999; Kay, Henry T. 1870 1970: Commemorating the Centenary of Glenside Hospital. Netley, SA: Griffin Press, 1970.

Maureen Bell

DIESENDORF, MARGARET (19121993), poet, teacher, editor, and translator, was born Margaretha Amalia Gisela, on 15 May 1912 in Vienna, daughter of Stefan Máté, tailor, and his wife Amalia Magdalena, née Maiwald. In her youth Margaretha was academically gifted, learning Hungarian, French, Latin, and English. She read widely in philosophy, philology, psychology, and educational theory, and had a particular interest in English and Austrian literature. At the University of Vienna (1930-38), she was awarded a $\mathrm{PhD}$ 
(1935) for her thesis 'The Literary Language of Expressionism'. This was followed by a master's degree in education. At the time of the Anschluss (March 1938) she was in France doing postdoctoral work. She returned briefly to Vienna before fleeing across the Swiss border to avoid the Nazi regime, fearing that her linguistic skills could make her vulnerable to being co-opted by the Nazis.

In Switzerland, Máté stayed with friends of Walter Diesendorf [q.v.14], a Jewish engineer and admirer, with whom she had been close since her student days. She followed him to Sydney in May 1939, where he had found work as an electrical engineer. Employed briefly (1939) at Sydney Church of England Girls' Grammar School, Moss Vale, she taught French and German. On 22 December at the district registrar's office, Woollahra, she married Walter. Living at Rose Bay, she taught French at Ascham School, Edgecliff, and at the Convent of the Sacred Heart (Kincoppal), Rose Bay. She was naturalised in 1944.

From the late 1940 s to the 1960s Diesendorf was involved in a number of social and education campaigns, including establishing a chair in Australian literature at the University of Sydney, and campaigning for increased research into poliomyelitis, an area in which she believed Australia was lagging behind other countries. Recognising the dangers of the indiscriminate use of radiation, she also succeeded in stopping the use of X-ray machines in shoe shops. An accomplished linguist, she translated the work of the German poet Rainer Maria Rilke into English. On a trip to Europe in 1960, she met the French poet Luis Dautheuil whose works she had also translated into English. This meeting led to their translating poetry between English and French, including Rosemary Dobson's L'Enfant Au Cacatoès (Child with a Cockatoo), published in Paris in 1967. A bilingual double issue of Poetry Magazine, published in 1964, contained twenty-four poems by sixteen Australian poets translated into French by Diesendorf and Dautheuil.

With her friend Grace Perry [q.v.18], the founder of South Head Press, Diesendorf collaborated on the journal Poetry Australia from 1964, serving as associate editor (196781 ). She continued to publish translations in English, French, and German, including the 1987 German-English volume, Der Körper
Der Altar (The Body the Altar), a selection of seventy-two poems by Perry. As guest editor (1980) of the American magazine Creative Moment, she translated Australian poetry into French. In the mid-1960s she worked for the Australian Broadcasting Commission translating interviews with contemporary French writers such as Louis Aragon and Alain Robbe-Grillet for the program Today's Writing. She corresponded with many authors including Robert Graves, A. D. Hope, Gwen Harwood [q.v.], D. J. Enright, and Judith Wright.

It was not until the early 1960s that Diesendorf began to focus on her own poetry. In 1972 and 1973 she received the Pacific Books Publishers best poems awards. A pamphlet of her poems, Towards the Sun, was published in 1975. She won first prize in the Borestone Mountain Poetry award (California) in 1974 and 1976 for 'Light' and 'The Hero', respectively. After her husband's death in 1975, she increased her creative output, her poems appearing in newspapers and journals in both Australia and the United States of America. Two collections eventuated: Light (1981), and a decade later, Holding the Golden Apple (1991). 'Spanning two cultures ...' she especially 'brought to her art, European cultural and literary traditions, the musicality and humour of her native Vienna, and the aesthetics of a classicist and philosopher' (Munro 1993, 4).

In her poetry Diesendorf explored love, music, and art. Vitality, generosity, warmth, and social reform characterised her life. In 1991 she moved to Canberra to be nearer her family. There she became part of the city's literary circles. Survived by her two sons, she died at Aranda on 22 April 1993 and was buried in Gungahlin cemetery.

Academy Library, University of New South Wales, Canberra. MSS 228, Margaret Diesendorf manuscript collection; Diesendorf, John. 'Light.' In Strauss to Matilda: Viennese in Australia, 19381988, edited by Karl Bittman, 24-34. Leichhardt, NSW: Wenkart Foundation, 1988; Munro, Patricia. 'A Life of Love and Vitality.' Canberra Times, 24 April 1993, 4; National Archives of Australia. A367, C54572; Wilde, William H., Joy Hooton, and Barry Andrews, eds. Oxford Companion to Australian Literature. Melbourne: Oxford University Press, 1994.

Judith BeVeridge 
DILLON, SIR JOHN VINCENT (JACK) (1908-1992), public servant, was born on 6 August 1908 at Charlton, Victoria, third of four children of Roger Dillon, hotelkeeper, and his wife Ellen, née Egan, both Victorian born. By 1916 the family had moved to Melbourne and Jack was educated at Christian Brothers' College, South Melbourne. What he saw in the pubs his father managed turned him into a teetotaller (Forbes 1974, 9). In 1925 he joined the Victorian Public Service and was employed as a messenger before being appointed as a clerk in the Law Department. For a time he was attached to the relieving staff and worked in courts across the State. He was clerk of courts at Swan Hill from 1930, and at Beechworth from 1934. That year he passed the police magistrates' qualifying examination, with honours.

On 8 January 1935 at Our Lady of Lourdes Catholic Church, Armadale, Melbourne, Dillon married Sheila Lorraine Darcy. They lived at Beechworth until 1938, when he was transferred to Melbourne as clerk of courts at Northcote and Preston. In 1939 he was voted president of the Clerks of Court Association. Two years later he was elected as the general service representative on the newly constituted State Public Service Board. Comprising a chairman, a government member, and employee members, the board oversaw the classification, recruitment, promotion, and general terms and conditions of Victorian public servants. He would remain in the role until 1954.

After several years of part-time study, in 1945 Dillon qualified as an accountant. In 1947 he was appointed a stipendiary magistrate, based at the busy city court in Russell Street. His youngest son recalled that when he and his siblings appealed to their father to settle a squabble, Dillon approached the task as if he was in a courtroom, instructing them to 'let the witness tell the story' (Braniff 2015, 7). From 1961 he was under secretary and permanent head of the Chief Secretary's Department. As one of the highest-ranked public servants in the State, he had diverse administrative responsibilities, including prisons, police, emergency services, and the licensing of liquor, racing, professional sport, gambling, and betting. With his minister,
Chief Secretary (Sir) Arthur Rylah [q.v.16], Dillon was closely identified with strict enforcement of censorship laws.

On 9 October 1973 Dillon was appointed as Victoria's first ombudsman. Responsible to parliament, he was charged with receiving and investigating complaints from citizens about the administrative actions of government and its agencies. His was a controversial selection, many considering him a tame cat' (Ellingsen 1975, 11) because of his long service as a senior bureaucrat. It soon became evident that he was determined to have the new office accepted by both the public and the administration. Former critics readily recanted their allegations that he lacked impartiality and integrity, when told that the highest number of complaints he upheld in his first year was against his old department. Described as a hot line' to authority (Ombudsman 1979, 24), his office investigated a range of grievances from poor prison conditions to poultry farmers' licensing disputes.

Hard-working and energetic, Dillon was accustomed to putting in regular night and weekend hours to meet his responsibilities. $\mathrm{He}$ also had an innate sense of fairness and a meticulous approach to fact finding. On Saturdays and during his lunch hour he made time for recreation, chief among them being attending horse races, and playing snooker, bowls, and golf. He was appointed CMG in 1974, knighted in 1980, and two years later awarded an honorary doctorate of laws by the University of Melbourne. As a prominent Catholic layman he was wary of being tagged a 'devout Catholic' in his public life, always expecting a pointed qualification or adverse criticism to follow. By the time he retired in August 1980, Sir John had investigated almost 13,000 written complaints, and made more than 120 recommendations to the government, the vast majority of which were implemented. Having battled bouts of cancer since the early 1970s, he died on 20 November 1992 in East Melbourne and was buried in Springvale cemetery. His wife, and their daughter and three sons survived him.

Braniff, Pauline. 'Father Kevin Dillon: A Life Less Ordinary.' Weekly Review (Geelong), 26 March 2015, 6-7; Ellingsen, Peter. "'Tame Cat" Ombudsman with a Tiger's Bite.' Australian, 15 April 1975, 11; Forbes, Cameron. 'The Ombudsman, and His Own Case.' 
Age (Melbourne), 19 February 1974, 9; Maslen, Geoff. 'The Big O Signs Off.' Age (Melbourne), 1 August 1980, 11; Sunday Age (Melbourne), 'State's First Ombudsman Proved the Critics Wrong.' 22 November 1992, 5; Victoria. Ombudsman. Annual Report. [Melbourne]: Victorian Government Printer, 1974-81, 1998, 2003; Wilkins, Sally. 'A Man Who'll Always Lend You His Ear.' Age (Melbourne), 21 December 1976, 8.

ReNN WORTLEY

DIQUE, JOHN CHARLES (19151995), haematologist, pathologist, and political activist, was born on 5 August 1915 at Mandalay, Burma (Myanmar), son of Indianborn parents John Stephen Dique, an assistant surgeon in the Indian Subordinate Medical Department (a component of the Indian Army), and his wife Norah Avice Georgiana, née Heyne. Both parents were descended from European colonists. The family moved to India, where John junior was educated at the Philander Smith College (a boarding school at Nainital) and the Madras Medical College, University of Madras (MB, BS, 1941). In addition to being a bright scholar, he was a capable sportsman, winning an all-India inter-university freestyle swimming championship.

On 31 October 1941 at St Joseph's Catholic Church, Vepery, Madras (Chennai), Dique married Doreen Delta Faith Bartley, a journalist, poet, and visual artist. With World War II in progress, earlier the same month he had been appointed as an assistant surgeon in the Indian Medical Department (captain, Indian Medical Service, from 1943). $\mathrm{He}$ worked in hospitals and other medical units at Rawalpindi; on the Burmese border, treating casualties of the Japanese invasion; and at Poona (Pune).

Disturbed by the political unrest in India after independence from British rule in 1947, Dique migrated with his wife and children to Australia, where he had relatives. He unsuccessfully sought work at hospitals in Perth, Adelaide, Melbourne, and Sydney, but secured an appointment in 1948 as transfusion and resuscitation officer at the Brisbane General (Royal Brisbane from 1966) Hospital. There, he developed improved sets for administering blood transfusions and a better apparatus for introducing fluids through the umbilical veins of infants suffering from erythroblastosis fetalis. His publications, some with his assistant, Dr Dorice Wrench, quickly gained him a reputation as an innovator in the field.

Dique further enhanced his standing when he and the hospital's chief electrician, Harold Lloyd, built a rotating-drum artificial-kidney machine based on the Dutch researcher Willem Kolff's design. On 10 February 1954 Dique used it to save the life of a young woman diagnosed with critical post-partum renal failure, the first time such a treatment had been performed in Australia. He later oversaw the construction of a second machine, modifying a design by the Swedish inventor Nils Alwall. Between 1954 and 1963 Dique, who meticulously documented his work and published the results, treated twenty patients with acute renal failure and achieved a 45 per cent survival rate.

In 1956 Dique became a founding fellow of the (Royal) College of Pathologists of Australia (Australasia). Despite the medical advances he pioneered, he was unable to save the life of his three-year-old son, David, who died from chronic renal failure in 1957. After this tragedy, he left clinical medicine and established a private pathology practice.

Retiring in 1984 after a coronary thrombosis, Dique devoted his time to lobbying on social and political issues, a practice he had begun in the mid-1960s. From those years he expounded reactionary views in letters to newspapers, an activity, he claimed, that was prompted by the Australian government's declaration of trade sanctions against Rhodesia (Zimbabwe) in 1965 . He extolled the merits of the White Australia policy and Australia's hereditary ties with Britain, often citing theories, propounded by Arthur Jensen and others, that linked mental capacities with race. Following the election of Gough Whitlam's Australian Labor Party government in December 1972, and the shift to promote multiculturalism as a basis for national identity, he became increasingly active as a political campaigner.

As president from 1975 of the Queensland Immigration Control Association, Dique published his militant racist beliefs in its monthly newsletter, News and Views (Queensland), and in a number of monographs, including Immigration: The Quiet Invasion (1985). He warned of the dangers of 'invasion' of Australia by 
migrants with non-European backgrounds; railed against increased taxation, charging that it resulted in a declining birth rate; and espoused liberty and free speech, claiming that anti-racist laws impinged on these values. The radical right-wing organisation the Australian League of Rights, of which he was a member, published several of his works. Joining the National Party, he asserted that the rank and file agreed with his opinions but were afraid 'of being called racist' (Crisp 1989, 48).

Dique was a devout Catholic. In his spare time he cultivated his garden at his Windsor home, played the violin, sang, practised recreational carpentry, and enjoyed the company of his children, grandchildren, and great grandchildren-what he called the 'Dique dynasty' (Dooley 1995, 201). Although personally frugal, he was generous to others. He died on 18 January 1995 at Chermside and was cremated. His wife survived him, as did their three daughters and three of their four sons. He left both a rich professional legacy and a reputation as an uncompromising racist.

Courier Mail (Brisbane). 'Medical Pioneer Dies.' 24 January 1995, 7; Crisp, Lyndall. 'Harvest of Hate.' Bulletin (Sydney), 4 April 1989, 42-49; Dooley, Desmond J. 'John Charles Allan Dique.' Medical Journal of Australia 163 (21 August 1995): 201; George, Charles R. P. 'John Dique: Dialysis Pioneer and Political Advocate.' In 'History of Nephrology 10', eds, Natale Gaspare De Santo1, Biagio Ricciardi, Boleslaw Rutkowski, Vincenzo Savica, and Athanasios A. Diamandopoulos, special issue, Giornale Italiano di Nefrologia (S66) (2016). giornaleitalianodinefrologia.it/wp-content/uploads/ sites/3/pdf/GIN_A33VS66_00232_13.pdf. Copy held on $A D B$ file; National Archives of Australia. A997, 1947/371.

Mark Cryle

DISNEY, MARION LOUISE (19161995), community worker, was born on 27 October 1915 in Kingston, Jamaica, eldest of three children of Horace Alexander Lake, a Jamaican-born lawyer, and his American wife Adelaide, née Requa. Following schooling in Jamaica, Marion went to Oxford (BA, 1938), where she joined the Society of Oxford Home Students (later St Anne's College) and studied philosophy, politics, and economics. After a brief time back in Jamaica as a journalist she returned to England. On 6 May 1939 at the register office, Watford, Hertford, she married Patrick Canning Wemyss Disney, a schoolteacher and fellow Oxford graduate. They took their vows again with Anglican rites on 17 September at St John's Church, Heronsgate.

During World War II Patrick served in the Reserve of Air Force Officers. He performed administrative duties at RAF stations and headquarters in England, North Africa, Malta, and Italy. Rising to the rank of acting wing commander, he was mentioned in despatches four times and appointed OBE (1945). Marion was a personal assistant to a director in the Air Ministry, before the birth of the first of her four children in 1941. The Disneys moved to Australia in 1952 following Patrick's appointment as headmaster of Scotch College, Adelaide. Marion became known for her friendliness and support of the students, especially those who were boarders.

After her husband died suddenly in 1961, Disney, with teenage children to support, found employment as the first full-time director (1962-80) of Adelaide's Citizens Advice Bureau (CAB), which had been established on a trial basis in 1958. Based on British models and the first of its kind in Australia, the bureau provided free advice on legal, financial, health, housing, and family concerns. By 1969 it was handling 3,000 enquiries per year. In 1972 Disney helped establish a national peak body, the Australian Association of Citizens Advice Bureaux, of which she was later president (1975-77).

Disney developed a Directory of Social Resources, a vital community resource, later taken over by the State government. In the late 1970s she helped establish an information centre in Port Adelaide and assisted the South Australian Women's Information Switchboard; in both cases she emphasised the importance of culturally appropriate services. She was an executive committee member (1963-78) and life member of the South Australian Council of Social Services (SACOSS) and helped found its very successful charity card shop. For over twenty years from 1965 she served on the council (later the executive committee) of the South Australian Association for Mental Health, of which her husband had earlier been a member. After retiring from the $\mathrm{CAB}$, she worked part time coordinating the Association for Relatives and Friends of the Mentally Ill. 
Appointed MBE in 1980 for service to the community, Disney was also a recipient of the Queen's silver jubilee medal (1977), the Adelaide Rotary service award (1978), and the SACOSS community services award (1982). She served on the Committee of Enquiry into Dental Services in South Australia (1980) and subsequently on the Dental Board. In retirement she was a Red Cross volunteer and in 1994 she was appointed to the State advisory committee for the International Year of the Family.

According to Barbara Garrett, a longterm president of SACOSS, Disney 'achieved an enormous amount without fuss, inspiring all those with whom she worked' (Noble $1995,12)$. She had a warm and gracious personality and was capable and well organised, successfully managing her busy life as a sole parent with a career. Survived by her three sons and daughter, she died on 26 July 1995 at Toorak Gardens, Adelaide, and was cremated. Hands On SA, an organisation providing employment opportunities for people with disabilities, established an annual award in her name. Two of her sons became Rhodes Scholars.

Disney, Hugh. Disneys of Stabannon: A Review of an Anglo-Irish Family from the Time of Cromwell. Basingstoke: Hugh Disney, 1995; Noble, Joy. 'Innovator of Public Advocacy.' Australian (Sydney), 9 August 1995, 12; Page, Michael F. The SACOSS Story. Adelaide: South Australian Council of Social Service, 2002.

Joy Noble

DOWNING, ROBERT REGINALD (REG) (1904-1994), politician, was born on 6 November 1904 at Tumut, New South Wales, eldest of four children of New South Wales-born parents Robert Downing, cordial manufacturer, shearer, and rural labourer, and his wife Frances Jean, née Galvin. Reg did not commence at Tumut convent school until the age of seven, due to the effects of scarlet fever, which had carried off his sister. His mother, who had been a teacher, ensured he was prepared and he quickly showed aptitude at his studies, winning a high school bursary to St Patrick's College, Goulburn. The family's poverty meant that he was forced to leave school at fifteen. There was little employment in Tumut so he moved to Sydney and found work as a labourer in the notoriously harsh environment of Bond's Industries Ltd's Camperdown dye house, in the scouring room.

Downing's parents were both stout supporters of the Australian Labor Party (ALP). He was soon active in the party and in the Australian Textile Workers' Union. Against strong opposition, he achieved some industrial successes for his fellow workers. This led to his becoming a full-time organiser and State president of the union in 1928. In 1934 he took office as State secretary, a position he held until May 1941. He was also Federal president of the union from 1934 to 1941.

On 11 April 1932 Downing had married Rose Moyeen Ashcroft (d. 1981), a typist, at Villa Maria Catholic Church, Hunters Hill. He described the day he met Rose as the best of his life. The following year he was badly injured when a car collided with a tram in which he was a passenger. He almost lost his leg and it remained a painful disability throughout his life. This and his new family responsibilities made him decide to study law. Security and prosperity beckoned at the Bar. Passing the University of Sydney matriculation exam in 1939, Downing graduated LLB in 1943; he was admitted to the Bar in March that year.

In the late 1930s, Downing had been heavily involved in the struggle against the New South Wales ALP leader, Jack Lang [q.v.9]. On 5 September 1939 Lang was replaced as leader of the Opposition by the moderate (Sir) William McKell [q.v.18]. Downing was a close ally of McKell, as he was of Ben Chifley [q.v.13] in the Federal ALP. $\mathrm{He}$ was a major figure in the group of anticommunist and anti-Lang union officials who controlled the State party from 1940 until 1952. With McKell's support, he was elected to the New South Wales Legislative Council on 23 April 1940. When McKell became premier on 16 May 1941, Downing was appointed minister of justice and also vicepresident of the Executive Council and leader of the government in the Legislative Council, where Labor lacked a majority until 1949.

Although a novice, Downing was respected by members of the council for his sincerity and reasonableness, and he was able to negotiate compromises to enable controversial bills to become law. Behind the scenes he was McKell's liaison with the 
extra-parliamentary Labor Party, successfully ensuring harmonious relations. As minister of justice he was responsible for corrective services. With an emphasis on rehabilitation, he reformed the prison system, setting up the Parole Board and the Adult Probation Service, and appointing a consulting psychiatrist to the Prisons Department.

After McKell resigned as premier on 6 February 1947, James McGirr [q.v.15] succeeded him. Downing had supported the education minister, Robert Heffron [q.v.14], an old friend from his Trades Hall days and McKell's preferred successor, in the leadership struggle. Relations with the new premier were not helped by a major internal crisis arising from the 1949 triennial election for the Legislative Council, a chamber indirectly elected by the members of both Houses. The small number of votes needed to be successful made council elections subject to manipulation. Downing heard rumours that a number of ALP votes were likely to leak to an Independent, (Sir) Asher Joel. He put in place a system of vote-checking. Four Legislative Assembly members broke the ticket and were refused endorsement by the ALP executive for the forthcoming election. McGirr unwisely intervened on their behalf and, when rebuffed, threatened to resign as premier. $\mathrm{He}$ soon withdrew his threat, but this internal chaos contributed to Labor's near defeat at the 17 June 1950 election. Increasingly beleaguered and alienated from his former allies, McGirr turned to Downing for support. Aside from his other attributes, Downing appealed to the suspicious McGirr because as an Upper House member he was not a leadership threat.

On 2 April 1952 Joe Cahill [q.v.13] replaced McGirr as premier. Downing and the astute, pragmatic Cahill had a natural affinity and were soon working together closely. Cahill quickly restored the government administratively and politically. The conflict in the Labor Party over the role of the industrial groups (formed to counter communist influence in the unions) was threatening to split the New South Wales branch by the mid1950s. Although a strong Catholic, Downing was a foe of the 'groupers', who at the 1952 annual conference had deposed the executive of which he was a key supporter. He worked hard to find a compromise that would preserve Labor in New South Wales. With Cahill's support, he negotiated with the ALP federal executive, the Sydney Catholic hierarchy, and the less extreme 'groupers'. He finally brokered a deal in 1956 that left moderates from both sides in control. When the Democratic Labor Party was formed, it had slight support in New South Wales. B. A. Santamaria, the head of the Catholic Social Studies Movement and a key force behind the groups, later said that there was no major split in New South Wales 'largely because of the efforts' of Downing (Santamaria 1997, 164).

Cahill died in office and was succeeded by Heffron on 23 October 1959. Although dynamic in his youth, Premier Heffron had mellowed into an ineffectual and conflictaverse figure. He depended heavily on Downing, who was now at the peak of his power but also under much pressure. He was the target of an increasingly restive rebel group in the parliamentary party. An unsuccessful attempt by the government to abolish the Legislative Council, in accordance with ALP policy, led to a group of members leaving the party in 1959. Downing was back to being the leader of a government in the minority in the Upper House. He was both minister of justice and attorney-general from 15 March 1956 to 31 May 1960, when he shed justice.

One of the attorney-general's responsibilities that Downing took particularly seriously was appointing judges. In 1960 the position of chief justice of New South Wales became vacant. The Federal ALP was seeking to ease out its leader, H. V. Evatt [q.v.14], and pressure was put on Heffron to appoint him to the position. He agreed, but Downing refused, believing that Evatt had deteriorated mentally to such an extent that he was unsuitable for the role. Downing kept the cabinet evenly divided between pro- and anti-Evatt forces for a month in early 1960. Finally, one of his supporters defected and Evatt became chief justice. Downing's forebodings proved justified.

Downing was next involved in a major internal power struggle over the proposed legalisation of off-course betting. Illegal bookmakers were lobbying hard to operate the system. He favoured a governmentcontrolled totalisator board. Senior ministers and government members were rumoured to have been bribed by the illegal operators. Downing countered by arranging for the ALP executive to direct the government to establish a totalisator system. After much tortuous 
manoeuvring, he finally carried the day and the Totalisator Agency Board was established in 1964.

Labor lost office at the 1 May 1965 election. Downing became leader of the Opposition in the Legislative Council, and also built up a practice at the Bar, becoming a QC in 1973. He helped to arrange for the future New South Wales premier Neville Wran, whom he had mentored, to succeed him as Opposition leader in the Upper House. On 4 February 1972 he left parliament, retiring to a sheep property at Goulburn that he had purchased in 1946 from McKell. That year the University of Sydney conferred on him an honorary doctorate of laws; he had been a fellow of the senate of the university from 1949 to 1967 . In 1979 he was appointed AC. The Downing Centre court complex in Sydney was named in his honour in 1991.

A short, nuggetty man with 'a winning smile' and 'a preference for self-effacement' (Clune 2006, 229, 243), Downing was one of the people who made it possible for Labor to govern in New South Wales for twentyfour consecutive years. Time and again he negotiated deals and compromises to avoid conflict and political damage. He used his behind-the-scenes influence to improve legislative outcomes. His tactics were astute and tough, but not unscrupulous. Wran described him as an indefatigible [sic] man with a Robert Bruce-like devotion to any task he undertakes', and as 'a man whose basic integrity has won him the esteem of not only his political supporters but his political opponents as well' (NSW Parliament 1972, 4273). John Hannaford noted that his contributions to the law included pioneering measures in consumer law, women's rights and uniform national companies legislation', as well as 'play[ing] a major role in establishing the Suitors Fund and law reform committees', and 'actively pursu[ing] the abolition of capital punishment in New South Wales' (NSW Parliament 1994, 2874).

Downing was keenly interested in racing. When one of his horses was running, all business in the ministerial office came to a standstill. His brother Frank was the ALP State member for Ryde (1953-68); his cousins Thomas O'Mara, Billy Sheahan [q.v.16], and Terry Sheahan were also members of the New South Wales Legislative Assembly. Predeceased by a daughter and survived by two sons, he died on 9 September 1994 at Goulburn and was buried in St Patrick's cemetery, Kenmore.

Clune, David. 'Labor Master of Backroom Deals.' Australian, 22 September 1994, 15, 'The McKell Style of Government.' In McKell: The Achievements of Sir William McKell, edited by Michael Easson, 119-54. North Sydney: Allen \& Unwin Australia, 1988, 'Reg Downing: A Safe Pair of Hands.' In The Worldly Art of Politics, edited by Ken Turner and Michael Hogan, 228-45. Leichhardt, NSW: The Federation Press, 2006; Clune, David, and Ken Turner, eds. The Premiers of New South Wales, 1856-2005. Vol. 2, 1901-2005. Leichhardt, NSW: The Federation Press, 2006; Downing, Robert Reginald. Interview by David Clune, 19 December 1986. New South Wales Parliamentary Library; Downing, Robert Reginald. Interview by David Clune and Ken Turner, 10 April 1987. New South Wales Parliamentary Library; Downing, Robert Reginald. Interview by R. Raxworthy, 5 October 1990. New South Wales Parliamentary Library; Hogan, Michael, and David Clune, eds. The People's Choice: Electoral Politics in 20th Century New South Wales. Vol. 2, 1930 to 1965. Sydney: Parliament of New South Wales and University of Sydney, 2001; New South Wales. Parliament. Parliamentary Debates, 16 February 1972, 13 September 1994; Santamaria, B. A. Santamaria: A Memoir. Melbourne: Oxford University Press, 1997; State Library of New South Wales. MLMSS 2310, Robert Reginald Downing Papers, c. 1941-1965.

David Clune

DUERRIGL-KNEZ, BRUNO (19211995), community leader and theatre director, was born on 16 April 1921 at Maribor, then part of the Kingdom of Serbs, Croats, and Slovenes (Kingdom of Yugoslavia from 1929), son of Croatian-born Alfred Dürrigl and his Slovenian-born wife, Elly. Bruno used the surname Duerrigl-Knez, combining the family names of his paternal grandparents. Raised at Zagreb, he began working in theatre during his teenage years. After matriculating, he embarked (1939) on a medical degree, but soon abandoned it to pursue studies in theatre and radio journalism in Vienna. On his return to Zagreb in 1942, he worked in radio. During the final year of World War II, he left Croatia as a refugee and lived in displaced-persons' camps in Austria. On 18 May 1950 he married Zdravka (Vally) Meyer, also a refugee, in Salzburg. A widow and trained artist, Vally had been born on 25 August 1919 at Zagreb, daughter of Croatian parents Otto and Ana Meyer. The 
couple had first met at Zagreb. In Austria they worked together organising cultural events for the British occupation forces, including in the camp at Graz. Bruno and Vally migrated to Australia under the auspices of the International Refugee Organization resettlement scheme. They arrived in Melbourne aboard the Protea in December 1950, moving to Adelaide soon after.

Bruno was variously employed as a porter for the South Australian Railways, a salesman, and a painting contractor. He and Vally were active in Croatian community life. In 1951 he produced and participated in a folkloric performance by Croatian migrants as part of a 'New Australian Festival of Arts' at the Adelaide Town Hall. He liaised between arrivals and support organisations, including the Catholic Migration Centre and the Good Neighbour Council of South Australia, and later also trained producers and presenters of the Croatian community radio program. From the mid-1950s the couple became widely known by the shortened surname Knez. They were naturalised in January 1958.

Determined to pursue a career in theatre, Bruno taught drama in schools and acted in and directed many productions in the 1960s. He was involved with the Therry Dramatic Society, the Lutheran Seminary drama club, the University of Adelaide Theatre Guild, Adelaide Repertory Theatre, the Pioneer Players, and Theatres Associated. By 1964 he had founded the Contour Players and had won several drama prizes including at the Adelaide Eisteddfod. A proficient actor, he appeared in some of his own stage productions as well as the film Breaker Morant (1980), but was known primarily for his directing. Vally worked as an art teacher in high schools, devoting much of her spare time to the couple's theatrical pursuits.

When Bruno and Vally founded La Mama Intimate Theatre in October 1972, they fulfilled a long-held ambition. He was artistic director, and she designed and created sets and costumes. La Mama became known as one of Adelaide's smallest but 'most indomitable' theatres (Harris 1986, 17). Modest and sparse, it was situated in Crawford Lane at Hindmarsh, an inner suburb. It comprised a small cellar theatre, an art gallery, and, eventually, a larger theatre across the lane-The Shed. La Mama stood for alternative, experiential 'theatre with a difference'. Bruno conceptualised La Mama as a place where audiences would not be mere 'spectators' but part of an 'aesthetic and theatrical' event (Weekly Times 1972, 18-19).

Expressionistic, experimental, and often deliberately provocative, Knez's direction was unmistakeable. He maintained an intellectual rigour that reflected his central European cultural origins. He had a sophisticated appreciation of music and used it to great effect in his productions. His energy and enthusiasm were boundless. By 1980, after twenty-five years working in Adelaide theatre, he had directed over 100 plays. The annual program at La Mama generally comprised five or more major productions, special shows for the Adelaide Festival of Arts or Fringe festival, and children's pantomimes. The repertoire was ambitious and the seasons long. He embraced Australian playwrights and acquainted audiences with the classics of contemporary American drama, as well as producing the works of Bertolt Brecht, Fernando Arrabal, Luigi Pirandello, Dylan Thomas, and Steven Berkoff, to name a few. The Glass Menagerie and Who's Afraid of Virginia Woolf?, both of which were staged multiple times, were among the most memorable La Mama productions. One of Knez's last shows was the Croatian renaissance farce Uncle Maroje (1989).

The 'curriculum plays' (performances of set texts for matriculation English) catered to school-aged audiences. La Mama's staging of The Crucible, The Caretaker, Death of a Salesman, Macbeth, The Club, and The Christian Brothers, among others, introduced thousands of students to live theatre. This program was hailed as one of Knez's great achievements. His minimalist style, the innovative sets, and his easy rapport with the students were integral to the success of these productions. La Mama became an inclusive cultural centre. Vally gave lessons in design, and Bruno conducted (method) acting classes and workshops for children. The unemployed attended at no cost. Students often performed in the productions and Bruno provided opportunities for local writers, directors, designers, and theatre technicians. A 'soft hearted disciplinarian' (Harris 1986, 17), he imposed demanding rehearsal schedules and had exacting standards. He was known for occasional volatile outbursts, but he had a sharp wit and was much liked. Over the 
years he garnered a wide and loyal following that included the Labor premier and minister for the arts John Bannon.

Knez was the quintessential bohemian, instantly recognisable by his signature moustache and goatee, flowing mane, black skivvy, heavy pendant, and baggy, light tan slacks. Financially, he and Vally struggled to keep La Mama afloat and only managed to make ends meet with periodic government grants. Although he never enjoyed good health, he kept working after major heart surgery in 1980, retiring in 1990 . He believed passionately and absolutely in the social function and transformative power of live theatre and had launched many careers in the arts. Survived by their daughter, and one of their two sons, Bruno died on 15 March 1995 at Woodville and Vally on 24 June 2000 in Adelaide. They were buried in North Brighton cemetery. Many recall fondly Bruno's preshow talks and his enduring catchphrase: 'If you enjoyed the show tell your friends, if not, tell your enemies.'

Addinall, Mark. 'La Mama Founder Brought New Vision.' Advertiser (Adelaide), 17 March 1995, 8; Advertiser (Adelaide). 'Bruno Knez: 25 Years in Adelaide Theatre.' 7 June 1980, 26; Advertiser (Adelaide). 'Mother, Teacher, Artist, Designer: She Loves Life.' 29 September 1966, 30; Harris, Samela. 'La Mama's Papa Fights for Survival.' Advertiser (Adelaide), 19 July 1986, Magazine 17; HR-HDA [Hrvatski državni arhiv, Croatian State Archives]. 1561 Služba državne sigurnosti Republičkog sekretarijata unutarnjih poslova Socijalističke republike Hrvatske, dossier Bruno Durigl Knez; National Archives of Australia. D400, SA1957/1380, D4878, Duerrigl-Knez B; D4878, Duerrigl-Knez Z; News. 'Mr Knez Calls the C.I.B.' 7 July 1965, 33; Performing Arts Collection, Adelaide Festival Centre. La Mama Theatre (Hindmarsh) Collection; Personal knowledge of $A D B$ subject; Weekly Times. 'Theatre with a Difference.' 11 October 1972, 18-19.

Vesna Drapac

DUGAN, DARCY EZEKIEL (19201991), robber and serial escapee, was born on 29 August 1920 at Newtown, Sydney, elder son of Victorian-born Ezekiel David (Richard) Dugan, mason, and his New South Wales-born wife Nonie, née O'Connor. With a strong Irish Catholic background, Darcy attended St Benedict's School, Chippendale. Before his teens he began shoplifting in and around Annandale with schoolmates who included Lenny (Lennie) McPherson. He became a juvenile cat burglar with a fascination for locks.

In 1937 Dugan was found guilty of stealing from his uncle's hotel and sentenced to a term in Gosford Farm Home for Boys. During this sentence he experienced brutal treatment by prison guards and other boys. His escape from the centre was the beginning of a long cycle: crime, capture, bashing, gaol, and escape. Before he was twenty-one, he had served time at Long Bay Penitentiary, Emu Plains Prison Farm, Goulburn Reformatory, and the Oberon Prison Farm.

After his release from Oberon, Dugan enlisted in the Citizen Military Forces for service in World War II and on 2 June 1942 began full-time duty in Sydney. On 10 June he was posted to Cowra to train as a sapper but on 22 July he absented himself without leave. While on the run, he committed a burglary for which on 7 October at the Sydney Quarter Sessions he was sentenced to two years imprisonment. He was discharged from the army the same day. After a sentence in Bathurst gaol, he taught ballroom dancing in Sydney studios, as he had done between previous periods of incarceration.

Crime rather than his passion for dancing, however, dominated Dugan's life. In January 1946, with Harry James Mitchell, he escaped from a prison van taking prisoners from Darlinghurst to Burwood. Recaptured and facing court in March 1946, he cut a hole in the roof of the prison tram and escaped with another prisoner near Centennial Park. Captured a day later, he was sentenced to three and a half years in Bathurst gaol. On his release in 1949 he changed his name by deed poll to Darcy Clare, took a job in a warehouse, and began saving for a truck.

This plan was soon curtailed. In August 1949 he was remanded in custody to Long Bay gaol after a failed robbery with William Mears. The pair escaped within two hours but were recaptured little more than a week later. Judge Adrian Curlewis [q.v.17] gave Dugan and Mears each a ten-year sentence. In December that year, Dugan asked Mears to call him as a witness in another matter, and began planning an escape from the Central Court of Petty Sessions. He sawed through cell bars, allegedly wrote 'Gone to Gowings' - a popular advertising slogan-on the cell wall, and both escaped. 
On 13 January 1950 Dugan and Mears robbed the Ultimo branch of the Commonwealth Bank of Australia. Mears shot and seriously injured the bank manager, and in February Detective Sergeant Ray Kelly [q.v.14] and others arrested both at Collaroy. This would be the first of four arrests by Kelly of Dugan. In court in May, Dugan made an unsuccessful attempt to escape. In June 1950 Justice Leslie Herron [q.v.14] sentenced Dugan and Mears to death for the Ultimo bank shooting. The McGirr [q.v.15] Labor government, re-elected later that month, commuted their sentences in December to life imprisonment in Grafton gaol.

At Grafton Dugan experienced a regime of brutal treatment for those considered never likely to reform. Twice he unsuccessfully attempted escape, and he was involved in a failed large-scale break-out. A petition to the New South Wales governor, Sir John Northcott [q.v.15], in 1953 — signed by 200 people, including the Anglican bishop of Canberra and Goulburn, Ernest Burgmann [q.v.13] — called for him and two others to be released from solitary incarceration. Another petition from 5,000 residents of Grafton had called for an end to the system in use at the gaol for dealing with prisoners considered intractable. Neither succeeded. In 1956 Dugan was transferred to Parramatta gaol.

Parramatta became another escape challenge for Dugan, who had come to be known as 'Houdini'. After an unsuccessful attempt in 1958, he was returned to Grafton. In August 1960 he was transferred to Long Bay and, after some minor trouble, returned to Grafton in May 1961, then to Parramatta in 1963, followed by Brookfield Afforestation Camp Mannus, Long Bay, Parramatta, and Bathurst gaol. His exploits attracted the attention of New South Wales ministers. In 1960 the attorney-general, Reg Downing [q.v.], had recommended consideration of his release in 1964 subject to good behaviour. Jack Mannix (the minister of justice) also visited Dugan and restated Downing's advice.

Released from Bathurst on licence in September 1967, Dugan worked as a counsellor at the Wayside Chapel, Kings Cross; became a popular speaker at service clubs; starred in the play Fortune and Men's Eyes; and began campaigning against police corruption and brutality in gaols. He was arrested for a jewellery store robbery in 1969 and sentenced in May 1970 to fourteen years gaol, which he spent alternately at Maitland gaol and Long Bay. His evidence to the royal commission into New South Wales prisons (1977-78) led to significant changes in the treatment of inmates. In 1971 and 1974 he had sued Mirror Newspapers Ltd for defamation, and in December 1978 lost an appeal to the High Court of Australia on the grounds that he was a prisoner at the time of the alleged defamation.

In May 1980 Dugan was released, having spent more than half his life in gaol. On 12 July that year he married Janice Florence Jackson, née Simmonds, a widowed proprietress of a health studio, at the Wayside Chapel of the Cross, Potts Point; she was the sister of Kevin Simmonds [q.v.16], another robber and gaol escapee. The couple lived in Canberra. Arrested in July 1981 for an attempted armed robbery, he was gaoled once more. In November 1985 he was released. In prison he had begun to paint, and several of his paintings were auctioned in an exhibition at Mudgeeraba, Queensland. He and Jan separated, and he moved to Glebe House, a halfway house in Sydney. Having suffered a stroke in 1985, he died on 22 August 1991 at Cabramatta, and was buried at Rookwood cemetery. The folk singer Bob Campbell told Dugan's story in song, and his autobiography, Bloodhouse, written with Michael Tatlow, was published in 2012.

Hay, Rod. Catch Me If You Can: The Life and Times of Darcy Dugan. Sydney: Sun, 1992; Morton, James. Maximum Security: The Inside Story of Australia's Toughest Gaols. Sydney: Pan Macmillan Australia, 2011; National Archives of Australia. B884, N187540; State Library of New South Wales. MLMSS 7198, Frank Fahy - Scrapbook of an Undercover Policeman, 1920-1952; Young, Brent M. 'Dugan v. Mirror Newspapers Ltd.' Monash University Law Review 4, no. 1 (December 1977): 81-86.

Glenn Mitchell

\section{DUGGAN, JOHN EDMUND (JACK)}

(1910-1993), politician, was born on 30 December 1910 at Port Augusta, South Australia, eldest of six children of Queenslandborn parents John Stephen Duggan, auctioneer and storekeeper, and his wife Charlotte Mary, née Matthisen. Although Catholic, Jack attended state schools at Hergott Springs (Marree) (1916 and 1921-22) and Hoyleton 
(1917-20). He worked as a junior messenger with an Adelaide wholesale grocer and, briefly, as a fruit-picker at Berri. Following the deaths of his mother (1922) and father (1924), his siblings went to live with an uncle, Maurice Duggan, at Toowoomba, Queensland, and he followed in March 1925.

Rejected for various office positions, Duggan worked as a shop assistant with the Downs Co-operative Stores Ltd and embarked on a vigorous program of self-education and self-improvement: reading voraciously, joining a debating society to improve speech and diction, and achieving minor success in athletics. In later life he would take up tennis and acquire a taste for classical music. While undertaking compulsory (from 1928) and then voluntary (after October 1929) service in the 25th Battalion, Citizen Military Forces (CMF), he decided to seek a career as a professional soldier. He gained promotion to lieutenant in August 1929, hoping to improve his chances of selection for the Royal Military College, Duntroon, Federal Capital Territory. His ambition was thwarted, however, by cuts in the defence budget and what he perceived as class discrimination. After a period of severe mental depression, he abandoned the army in 1933 and devoted himself to trade unionism and the Australian Labor Party (ALP).

By 1933 Duggan was vice-president of the Toowoomba branch of the Queensland Shop Assistants' Union, secretary of the city's Trades and Labour Council, and president of the local branch of the ALP. On 14 December 1935 he comfortably won a by-election for the State seat of Toowoomba. He married Beatrice Mary Dunne, a dressmaker, on 26 December that year at St Patrick's Cathedral.

Described as 'clean-living' (Chronicle $1935,4)$ and as 'a dapper, chubby-faced young man with slicked-back hair', 'a wide smile', and 'the self-possession of a matinee idol' (Courier Mail 1936, 14), Duggan had conducted a polished election campaign that impressed seasoned political reporters, one of whom dubbed him 'the boy who carries the A.L.P. banner' (Connolly 1936, 2). Within a year some informed commentators regarded him as a future premier. His confident and erudite maiden speech, delivered at a fast-paced 220 words per minute on 25 August 1936, sorely tested Hansard reporters. His parliamentary speeches in the aftermath of the Depression demonstrated his discontent with the world and showed more than a passing acquaintance with socialist and left-liberal ideas, especially those of Harold Laski and J. M. (Baron) Keynes; he was an early subscriber to the Left Book Club from 1936. Despite his abilities, his political progression was hampered partly by Premier Forgan Smith's [q.v.11] muted antagonism towards him but mostly by his own refusal to join a faction: 'I always had this view that I would stand on my own legs and I either succeeded as Duggan or I failed as Duggan, not just some nincompoop from a faction' (French 2016, 160).

On 27 September 1940 Duggan was reappointed as a lieutenant in the $\mathrm{CMF}$ and posted to his old unit, the 25th Battalion. Granted leave from parliament and recently promoted to captain, he began full-time duty on 17 September 1941. He transferred to the Australian Imperial Force on 10 July 1942. The battalion arrived at Milne Bay, Papua, later that month. As commander of 'D' Company and Clifton Force, he initially reconnoitred the Dogura region but returned to Milne Bay on 31 August, towards the end of the battalion's involvement in the major battle that had begun six days earlier. His appointment on 26 November as adjutant of the battalion was interrupted by staff training in Australia between April and August 1943. From October he was a staff captain at 7 th Brigade headquarters, near Port Moresby. Failing eyesight prompted his repatriation in January 1944, transfer to the Reserve of Officers on $21 \mathrm{March}$, and return to parliamentary duties. He did not claim his service medals. The mateship he experienced in the army in World War II gave him 'a revised estimate of my fellow man' (Truth 1954, 19) and a more positive view of the world.

Appointed as minister for transport on 15 May 1947, Duggan would hold this office until 29 April 1957. He was confronted with a railway network debilitated by wartime service and an aggressive road-transport lobby based at Toowoomba. After a tour of American and European railways (April-July 1951), he oversaw the introduction of the first diesel locomotives and air-conditioned trains in Queensland and planned the electrification of Brisbane's suburban lines. The road hauliers' challenge to licences and road taxes, their internecine feuds, and their abuse of section 
92 of the Constitution (requiring free trade between the States) raised legal issues during his term that would culminate under his Liberal Party successor, (Sir) Gordon Chalk [q.v.].

The 'factionless' Duggan was elected as deputy premier in January 1952, the third member of an uneasy triumvirate-with the premier, Vince Gair [q.v.14], and the treasurer, E. J. Walsh [q.v.16] — in a Catholic-dominated ministry. When the fissures between the ALP party organisation and the Gair government became a chasm-notionally over the question of three weeks annual leave but essentially over the Industrial Groups' challenge to the traditional party dominance by the Trades Hall-Duggan, though increasingly distant from Gair and the 'groupers', nevertheless attempted to bridge the animosities by compromise and negotiation; he failed. Although opposing the Queensland central executive's decision to expel Gair in April 1957, he refused to be part of the collective ministerial resignation and to join Gair's Queensland Labor Party. Instead, displaying a mate's loyalty to the party that had nurtured him, he became leader of the official, rump ALP. In the following vituperative election campaign (August) Toowoomba's Catholic hierarchy, both clerical and lay, demonised Duggan (and his wife, who was snubbed in the street by former friends). He bore the calumny stoically and calmly. With the QLP candidate taking 16.9 per cent of the vote, he gained only 38.7 per cent, enabling the Liberal aspirant to win with 41.2 per cent.

After unsuccessfully contesting the seat of Gregory at a by-election in October 1957, Duggan dismissed a move to Federal politics and established himself briefly as an industry consultant and share trader until he was re-elected (with comfortable majorities) for North Toowoomba at a by-election in May 1958 and Toowoomba West at the general election two years later. As leader of the ALP and of the Opposition from 1958, he had to contend with a resurgent Country and Liberal parties' coalition and with the growing influence of (Sir) Jack Egerton in the Brisbane Trades Hall. He resigned on 11 October 1966 as a self-imposed penalty for inadvertently failing to declare capital appreciation on shareholdings in his tax returns from 1955 to 1962; all political leaders expressed sympathy.
However, he had surrendered any chance of becoming premier and he retired from State politics on 17 May 1969.

On 4 April 1970 Duggan was elected to the Toowoomba City Council, serving as deputy (1970-81) to Nell Robinson, Queensland's first female mayor; as her successor from 27 August 1981 to 27 March 1982; and as a very effective honorary treasurer (1972-81) of the Local Government Association of Queensland. The Robinson-Duggan administration, husbanding funds for a third city dam, was noted for its anti-development stance, its parsimonious financial administration, and low rates. He was appointed AO (1982) for services to parliamentary and local government.

Duggan died on 19 June 1993 at Toowoomba. His wife had predeceased him in 1984 and his son and daughter survived him. Following a Catholic funeral, he was buried in the Drayton and Toowoomba lawn cemetery. Eulogised by both sides of politics, he received the most apt tribute from the local paper:

In his heyday, the Labor man was the most popular politician Toowoomba had ever known. So popular was he, in fact, that conservative voters would admit openly that they had voted for Jack Duggan-and their associates would understand (Chronicle 1993, 10).

Although born in South Australia, and despite the setback of the ALP split, he became Toowoomba's favoured son. A local park and street were named in his honour.

Chronicle (Toowoomba). 'Farewell to a Man Who Served Us Well.' 22 June 1993, 10; Connolly, Roy. 'Toowoomba is Proud of the Boy who Carries the A.L.P. Banner.' Daily Standard (Brisbane), 11 December 1935, 2; Courier Mail (Brisbane). 'Gallery Notes: Back to Work: Two Make Debut.' 26 August 1936, 14; Dick, Ian. 'Wounds Heal after 40 Years.' Chronicle (Toowoomba), 12 August 1994, 12; French, Maurice. Jack Duggan: A Political Biography. Vol 1, The Boy Who Would Be Premier. Toowoomba: Tabletop Publishing, 2016; French, Maurice. 'The Making of a Queensland Politician: Jack Duggan's Life before Parliament 1910-1935.' In From The Frontier: Essays in Honour of Duncan Waterson, edited by Paul Ashton and Bridget Griffen-Foley, 76-88. St Lucia, Qld: University of Queensland Press, 2001; French, Maurice. Toowoomba: A Sense of History 1840-2008. Toowoomba: University of Southern Queensland, 2009; National Archives of Australia. B883, QX36184; Toowoomba Chronicle and Darling Downs Gazette. 'Toowoomba Seat: Labor Plebiscite: 
Mr. J. E. Duggan's Success: Attitude of the Q.C.E.' 9 December 1935, 4; Truth (Brisbane), 'Rivals Call Him the Boy Wonder.' 3 January 1954, 19.

M. FRENCH

D. B. WATERSON*

DUGUID, PHYLLIS EVELYN (19041993), teacher, and Aboriginal and women's rights advocate, was born on 16 October 1904 at Hawthorn, Melbourne, third of six children of locally born parents Frank Lade [q.v.9], Methodist clergyman, and his wife Lillian Frances, née Millard. Both parents were actively involved in the temperance movement, her father travelling extensively to give lectures. The family moved to Adelaide in 1911, and Phyllis attended Miss Henderson's school for girls, and Methodist Ladies College, before studying classics and English at the University of Adelaide (BA Hons, 1925), where she also gained a Blue in hockey. She was strongly supported by her mother, saying that 'she wouldn't allow any of us just to stay home and be what was called a homegirl, until we had done something else' (Duguid 1982, 4). After working briefly as a tutor in English at the university, she became senior English teacher at the Presbyterian Girls' College. On 18 December 1930 at the Methodist Church, Kent Town, she married Charles Duguid [q.v.17], a surgeon.

Two things sparked Duguid's interest in Aboriginal issues. A long-term patient of Charles told stories of conditions in Central and Northern Australia, followed by the widely reported case of an Aboriginal man, Dhakiyarr (Tuckia) [q.v.Supp], in which the High Court (1934) found that he had been wrongfully convicted of murdering a police officer and sentenced to death. Following Charles's visit to the Pitjantjatjara and Yankunytjatjara lands in 1935, Phyllis supported his proposal to establish a mission based, in contrast to practices of the time, on the principles of respect for culture and language. With the support of the Presbyterian Church and the government of South Australia, Ernabella Mission opened in 1937. Together with M. E. Eaton, the president of the Women's Christian Temperance Union (WCTU), she visited Central Australia in 1938 to investigate reports of abuse of Aboriginal women. As a result of their journey, they formed the League for the Protection and Advancement of Aboriginal and Half-Caste Women, with Phyllis as the founding president. It became the Aborigines Advancement League of South Australia (AALSA) in 1950.

During the late 1940s Duguid actively supported her husband's campaign against the creation of a military firing range at Woomera with a flight path over Aboriginal reserves. In 1944 she fostered a six-year-old Aboriginal boy, Sydney James Cook, who had been enrolled at King's College, Adelaide. He lived with the family until 1950 when he was sent to Roper River in the Northern Territory, the Duguids believing that he would benefit by growing to manhood in an Aboriginal community. In 1953 the Duguids organised a meeting in the Adelaide Town Hall where five Aboriginal people (George Rankin, Mona Paul, Peter Tilmouth, Ivy Mitchell, and Geoff Barnes) spoke about their experiences of discrimination. The Duguids encouraged them to train and seek work as nurses and teachers. Some, such as Lowjita O'Donoghue, became leaders of emerging Aboriginal movements. An outcome of this meeting was the establishment in November 1956 of Wiltja Hostel in suburban Millswood to accommodate Aboriginal girls from country regions attending secondary schools in Adelaide. Phyllis maintained a close interest in the hostel.

Identifying as a Christian socialist, Duguid extended her concerns to others she saw as members of an underclass in society, especially women and girls. She was a member of the WCTU, the University Women's Club (president 1932), and the statutory Children's Welfare and Public Relief Board (1945-66), which she later described as 'very rewarding work' (Duguid 1982, 16). Minutes of the board show that members were aware of abuse within some institutions and took action to address it. In 2004 a South Australian government commission of inquiry into the care of state wards found that the alleged sexual abuse occurred in every type of care from the 1940s onwards' (South Australia 2008, xiii).

Duguid held numerous offices in the League of Women Voters of South Australia, becoming its final president in 1979. In 1944 she had published a pamphlet, The Economic Status of the Homemaker, in which she advocated 'homes founded on the 
true partnership of men and women who are free, equal and interdependent' (Duguid $1944,11)$. She wrote on equal pay for equal work, and chaired the first meeting of the Status of Women Council in South Australia. She wrote and broadcast on issues such as temperance, prison reform, and prostitution. A love of literature enriched her writing and public speaking. Her sense of humour found expression in poetry, written for family and friends. Living by the conviction that 'even might itself hath not the power of gentleness' (Duguid, pers. comm.), she possessed wisdom, grace, and patience that complemented the determination of her husband.

Known to her Pitjantjatjara friends as Kungka (Woman), Phyllis was awarded the OAM in 1987 for service to Aboriginal welfare. She died on 9 March 1993 at Linden Park, survived by a son and a daughter. Her ashes were interred next to the remains of her husband at Ernabella. The Duguid Indigenous Endowment and related travelling scholarship, founded in memory of Phyllis and Charles, are administered by The Australian National University. The University of South Australia and Flinders University share the biennial Duguid memorial lecture.

Barnes, Nancy. Munyis Daughter: A Spirited Brumby. Henley Beach, SA: Seaview Press, 2000); Duguid, Phyllis. An Impression of Ernabella, by Mrs Chas Duguid. Melbourne: Board of Missions of the Presbyterian Church of Australia, 1938; Duguid, Phyllis. Interview by Mary Hutchison, 13 August 1982. Transcript. Australian Federation of University Women Oral History Project. State Library of South Australia; Duguid, Rosemary. Personal communication; Kerin, Rani. Doctor DoGood: Charles Duguid and Aboriginal Advancement 1930s-1970s. North Melbourne: Australian Scholarly Publishing, 2011; Edwards, Bill. Mission in the Musgraves: Ernabella Mission 1937-73, A Place of Relationships. Black Forest, SA: Uniting Church Historical Society (S. A.), 2012; South Australia. Parliamentary Papers, no. 229, 1 April 2008.

W. H. EDWARDs*

DUNLOP, SIR ERNEST EDWARD (WEARY) (1907-1993), surgeon, army medical officer, war veterans' advocate, and public figure, was born on 12 July 1907 at Wangaratta, Victoria, younger of two sons of Victorian-born parents James Henry Dunlop, farmer, and his wife Alice Emily Maud, née Payne. The family lived at Stewarton. While
Alice recuperated from a difficult second birth, her twin sisters cared for the boy at nearby Major Plains. Ernest attended the local primary school and Benalla High School, boarding during the week with an aunt. James had purchased Summerlea, a mixed wheat and sheep farm, near Stewarton in 1910; he sold it in 1922, after which the family lived together at Benalla. Young Dunlop completed his Leaving certificate in 1923 and commenced an apprenticeship with William McCall Say, a local pharmacist, the following year.

In 1926 Dunlop enrolled in a correspondence course at the Victorian College of Pharmacy. He moved to Melbourne the following year and, in 1928, in his final college examinations, won the college's gold medal and the H. T. Tompsitt Memorial Scholarship. Having decided on a career as a medical practitioner, he transferred to the University of Melbourne (MBBS, 1934; MS, 1937) in 1929, winning a residential scholarship to Ormond [q.v.5] College in his second year. It was during an Ormond initiation ritual that Dunlop acquired the nickname 'Weary', being a reference to his last name, which he shared with a tyre company; yet tired and weary he was not. An industrious and hard-working student, he was known to keep long hours, often surviving on little sleep. Despite this, his passion for life and a larrikin streak attracted him to participate in the richness of college life. During Ormond College's commencement revels, he rode into the city on the back of a lorry dressed as a fairy, his willingness to be involved in all manner of escapades ensuring his popularity. Dunlop also demonstrated a passion for defending moral causes that would stay with him for the rest of his life. In 1932 he was part of a group of angry students who manhandled the communist activist Sam White [q.v.18] at a university debating society meeting, Dunlop having perceived that White had tarnished the university's reputation.

Tall —6 feet 4 inches $(193 \mathrm{~cm})$-and strongly built, Dunlop was accomplished in sport, securing a half-Blue for boxing (1931) and a Blue for rugby union (1932). He was the university's amateur heavyweight boxing champion for 1932, and represented Australia in the third rugby Test against New Zealand in July that year. Fearing that he might lose 
ground in his studies, he declined a place in the Australian team in 1933, but played again in the first Test against New Zealand in 1934.

An enthusiastic citizen-soldier, Dunlop was appointed captain, Australian Army Medical Corps, in 1935. Commissioned in the Australian Imperial Force on 13 November 1939 in London, he was posted in January 1940 to the medical section of the AIF's Overseas Base in Palestine, and promoted in May to major. In the Greek campaign (April 1941) he served as AIF medical liaison officer between the British headquarters in Athens and the corps headquarters in the forward areas, gaining a reputation for fearlessness. Having assisted with the withdrawal to Crete, he was evacuated to Egypt in early May because of illness. The next month he was posted as senior surgeon of the $2 / 2 \mathrm{nd}$ Casualty Clearing Station at Tobruk, Libya. In July he assumed temporary command of the CCS, which moved to Egypt later the same month. Obtaining approval for a mobile operating unit-a concept he had long advocated - he raised and, from November, briefly commanded No. 1 Mobile Operating Unit, before returning to the 2/2nd CCS.

The unit arrived in Java in February 1942 and formed the nucleus of No. 1 Allied General Hospital, which opened at Bandoeng (Bandung) that month. Dunlop was promoted to temporary lieutenant colonel (substantive, 1945) and placed in command. Staff and patients entered captivity when the Allied forces capitulated to the Japanese on 12 March. As the commander of Commonwealth troops, Dunlop fostered education, sports, and entertainments under difficult conditions. In January 1943 the Japanese dispatched a column of some 900 men under his command, via Singapore, to south-west Thailand. The men of Dunlop Force were put to work constructing the Burma-Thailand railway.

Despite suffering intermittently from amoebic dysentery, beriberi, tropical ulcers, and malaria, Dunlop used his generalist surgical knowledge to save countless lives. He received supplies of food, money, and medicines from the heroic Thai merchant and resistance worker Boon Pong (Boonpong Sirivejjabhandu), though these were never enough to alleviate the hardships and brutality that led to the deaths of many prisoners. On a number of occasions, the Japanese subjected Dunlop to severe beatings and threatened him with execution. His physical control under extreme provocation from his captors earned him respect from his troops and helped to keep the survivors going through the difficult months of increasing pressure to complete their section of the railway. In October he took command of the hospital at Tarsau (Nam Tok) and in January 1944 the hospital at Chungkai (near Kanchanaburi). He spent the last fourteen months of the war at the large Nakom Patom (Nakhon Pathom) hospital camp under (Sir) Albert Coates [q.v.13], who appointed him as the medical economics officer responsible for raising money for the sick. Coates also put him in charge of surgery and physiotherapy.

Repatriated in October 1945, Dunlop transferred to the Reserve of Officers as an honorary colonel on 2 February 1946. $\mathrm{He}$ was appointed $\mathrm{OBE}$ and mentioned in despatches (both 1947) for his service. On 8 November 1945, at Toorak Presbyterian Church, Victoria, he had married his longtime fiancée, Helen Leigh Raeburn Ferguson, a biochemist.

Resuming civilian life, Dunlop entered private practice and was appointed honorary surgeon to out-patients, later in-patients, at the Royal Melbourne Hospital. Many of his patients were prisoners of war (POWs) or their wives; none were charged for their treatment. Demonstrating his ongoing commitment to their welfare, he served as president (1946-89) of the Victorian branch of the Ex-Prisoners of War Relatives Association for the next twentythree years. In August 1946 he opened an exhibition of watercolours and pencil sketches by the former POW Ray Parkin, who had created the artworks in captivity; Dunlop had concealed them beneath a table top, and brought them to Australia. He gave evidence that was later used at the International Military Tribunal for the Far East. On behalf of POWs, he sought 'reparations from the Japanese in compensation for suffering, disability, and loss of life resulting from inhuman treatment' (Dunlop quoted in Smith's Weekly 1947, 4).

Elected a fellow of the Royal Australian College of Surgeons in 1948, Dunlop worked as a consultant at the Royal Victorian Eye and Ear Hospital and Peter MacCallum [q.v.15] Clinic during the 1950s and 1960s. He quickly gained 
a reputation for taking on difficult surgeries and for performing long, complex procedures. While his status as a surgeon was unquestioned, some of his surgical colleagues chafed at his tendency to run over time in theatre, charging him with being unprofessional. Indeed some considered his surgical practices cavalier, with one colleague, Alf Nathan, describing them as 'pandoodlectomies'. Others accused him of ignoring his patients' quality of life after surgery. However, Dunlop rejected such criticisms; if his otherwise inoperable patients survived the procedure, and many did, they were generally grateful for the extra life his 'heroic' (Ebury 2009, 334) efforts had given them.

In the two decades after the war, Dunlop's attitude towards his former captors shifted from 'hatred' (Hetherington 1964, 22) to distrust to forgiveness. Under the Colombo Plan, in 1956 and 1958 he undertook surgical work in Thailand, Ceylon (Sri Lanka), and India, and later encouraged the training of Asian medical personnel in Australia. Believing that 'friendship between Australians and Asians [was] essential to lasting peace' (Hetherington 1964, 22), he supported efforts to increase understanding, serving as president of the Australian-Asian Association from 1963 to 1993. In 1969 he returned to South-East Asia during the Vietnam War as leader of the Australian surgical team caring for civilians. He had been appointed CMG in 1965 and was knighted in 1969.

Sir Edward maintained a high public profile. Chairman of the Prisoners of War Trust Fund (1968-77), he took an active role in community health, serving as president of the Victorian Foundation on Alcoholism and Drug Dependence (1970-82) and chairman of the executive committee of the Anti-Cancer Council of Victoria (1974-80). He was named Australian of the Year for 1976. His The War Diaries of Weary Dunlop, illustrated by prisoners' artworks, was published to great acclaim in 1986 and he was appointed AC in 1987. That year the Weary Dunlop Boon Pong Exchange Fellowship was established. Initiated by returned POWs in Western Australia, the fellowship brought Thai surgeons to Australia for further training.

Predeceased by Helen (d. 1988) and survived by his two sons, Dunlop died on 2 July 1993 at Prahran, Victoria. He was farewelled with full military honours at a state funeral at St Paul's Cathedral, at which the former governor-general Sir Ninian Stephen delivered the eulogy. His coffin was carried on a gun carriage to the Shrine of Remembrance and over 10,000 spectators lined the streets. His remains were later cremated and floated down the Kwae Noi. Weary's heroism and legacy is memorialised by prominent statues at Benalla, Melbourne, and Canberra. The last, a bronze sculpture located in the grounds of the Australian War Memorial, depicts him in later life as a humble, stoop-shouldered, approachable, and smiling man. Dunlop was inducted into the Australian Rugby Union Hall of Fame in 2008, the first Victorian to be given that honour. The Canberra suburb of Dunlop is named for him.

Canberra Times. 'The Knight Who Forgave His Tormentors.' 3 July 1993, 16; Dunlop, Alan J. Little Sticks: The Story of Two Brothers. Melbourne: Acacia Press, 1985; Dunlop, E. E. The War Diaries of Weary Dunlop: Java and the Burma-Thailand Railway, 1942-1945. Melbourne: Nelson, 1986; Ebury, Sue. Weary King of the River. Carlton, Vic.: Miegunyah Press, 2009; Geddes, Margaret. Remembering Weary. Ringwood, Vic.: Viking, 1996; Hetherington, John. 'Man at His Best Is a Noble Creature.' Age, 2 May 1964, 22; National Archives of Australia. B883, VX259; Smith's Weekly. 'Wants $£ 1000$ for Every POW.' 4 January 1947, 4.

Michele C. Horne Katie Anne Mills

DUPAIN, MAXWELL SPENCER (MAX) (1911-1992), photographer, was born on 22 April 1911 at Ashfield, Sydney, only child of Sydney-born parents George Zephirin Dupain, physical culture expert, and his wife Thomasine Jane (Ena), née Farnsworth. George, a pioneer in the physical fitness movement in Australia, had founded the Dupain Institute of Physical Education, Sydney, in 1900, and wrote extensively on physical education, diet, and nutrition. As a boy Max worked out at his father's gymnasium. He later attributed his Romantic nature to the combination of his father's French and his mother's Irish ancestry. The family lived on Parramatta Road, close to other members of the Dupain and Farnsworth families. Max accompanied his mother to Church of England services at St John's Church, Ashfield, but as an adult was not religious, attributing his views to his father's scientific rationalism. 
Educated at Ashfield Preparatory and Sydney Grammar schools, Dupain did not thrive academically, and did not complete the Leaving certificate. He enjoyed athletics, rowing, and the arts. In 1924 his uncle Clarence Farnsworth, an amateur photographer, gave him his first camera. His creativity in photography was recognised at Grammar through the award of the Carter memorial prize for the productive use of spare time in 1928. That year he joined the Photographic Society of New South Wales and presented his early works in the prevailing soft-focus Pictorialist style in the society's exhibitions. His contribution to the society's 1932 Interstate Exhibition of Pictorial Photography attracted praise from the eminent photographer and critic Harold Cazneaux [q.v.7].

Leaving school in 1930, Dupain was apprenticed to the photographer Cecil Bostock. His three years with Bostock gave him a rigorous technical training. At the same time, he attended evening art classes at Julian Ashton's [q.v.7] Sydney Art School and East Sydney Technical College, where he developed basic skills in drawing. In 1934, with financial support from his family, he opened a modest studio with a shared darkroom at 24 Bond Street. The timing was auspicious as Australia was recovering from the Depression and the demand for advertising, society, and celebrity photography was growing. Following his move to larger premises in the same building, he employed Geoffrey Powell (1937-38) and Damien Parer [q.v.15] (1938-39). The photographer Olive Edith Cotton joined his studio in 1934 as the general assistant. Dupain had met her in 1924 through his father's business partnership with her uncle Max Cotton; the couple married on 29 April 1939 in a Methodist service at her home; they separated in August 1941, and divorced in February 1944.

The patronage of the publisher Sydney Ure Smith [q.v.11] was crucial in establishing Dupain's career. In 1935 Ure Smith featured his work in Art in Australia and invited him to review J. T. Scoby's book on the international surrealist photographer Man Ray for The Home magazine. By the late 1930s Dupain was recognised as a leading modernist photographer whose work responded to the realities of contemporary life.
He experimented with different techniques, including photomontage and solarisation, and developed a style characterised by a dramatic use of light. Throughout his career his preferred medium was black and white photography. His subject matter was diverse, encompassing still lifes, landscapes, and cityscapes, and he was one of the first Australian photographers to focus on studies of the nude, both male and female. Ure Smith would later publish the first monograph on Dupain in 1948.

Dupain's passionate advocacy of modernist photography extended beyond his own commercial and personal work. From the late 1930s he played an important role as a commentator in photography magazines and later as photography critic for the Sydney Morning Herald. He was a founding member of the Contemporary Camera Groupe in 1938, formed to counter the prevailing conservatism of Australian photography. His Romantic outlook was shaped by his self-declared heroes in literature, music, and the arts: Beethoven, Shakespeare, D. H. Lawrence, Llewellyn Powys, and the Australian artist Norman Lindsay [q.v.10], whose book Creative Effort was particularly influential. His pantheon of photographers included Man Ray, George Hoyningen-Huene (whom he met in Sydney in 1937), and Margaret Bourke-White.

In 1941 the Dupain studio joined the photo-engraving firm Hartland \& Hyde Pty Ltd and relocated to Clarence Street. From 1942 to 1945 Dupain was employed in a civilian capacity as a camoufleur with the Royal Australian Air Force in Darwin, New Guinea, and Goodenough Island, off the north-east coast of Papua, taking photographs that revealed the effectiveness of different kinds of camouflage. Olive Cotton ran the studio in his absence. He joined the Commonwealth Department of Information in late 1945 and travelled around Australia taking photographs for the government's publicity campaign to attract migrants to Australia.

On 25 November 1946 Dupain married Diana Palmer Illingworth, a status clerk, at the District Registrar's Office, Chatswood; she later became a social worker. From 1953 until his death they lived at The Scarp, Castlecrag, in a house designed by the modernist Australian architect Arthur Baldwinson [q.v.13], and surrounded by a native garden cultivated by Dupain. In the postwar period 
his orientation in photography changed and he championed a documentary approach which involved working outdoors, using sunlight, and celebrating spontaneity and naturalness. Although he disdained the artificiality of the studio, he continued working in advertising but increasingly focused on architectural and industrial photography. He established close working relationships with eminent architects including Samuel Lipson, John D. Moore [q.v.10], Walter Bunning [q.v.13], and, in later years, Sydney Ancher [q.v.13] and especially Harry Seidler. A reluctant traveller, he made only one trip to Europe in his lifetime, in 1978, to photograph the Australian Embassy in Paris designed by Seidler.

During the 1970s Dupain emerged as a key figure in the Australian art photography movement following his retrospective exhibition at the Australian Centre for Photography, Sydney, which introduced his now best-known photograph, Sunbaker, to the public. This image encapsulated his interest in body culture and embrace of the outdoors: it came to be identified with a characteristically Australian way of life. Numerous shows and publications followed, along with representation in all major public collections in Australia, including the National Gallery of Australia. He had formed Max Dupain \& Associates in 1971, initially located at Artarmon, where colleagues included Jill White and Eric Sierins, and continued working until 1991.

Described by his second wife as a 'complex character' (Dupain 1993, 458), Dupain was not a social person and was intense, single-minded, and disciplined. His approach to photography was predicated on his belief that the viewer must be involved both emotionally and intellectually, and he devoted his life to achieving excellence in his practice. Becoming an honorary fellow of the Royal Australian Institute of Architects in 1980, he was appointed OBE in 1981 and AC in 1992. He died on 27 July 1992 at Castlecrag, survived by his wife and their daughter and son, and was cremated. After his death his archive was divided into two: the art and personal negatives remained with his family and the commercial negatives were consolidated into the Max Dupain Exhibition Negative Archive, now in the collection of the State Library of New South Wales.
Art Gallery of New South Wales. MS2000.3, Papers of Max Dupain; Crombie, Isobel. Body Culture: Max Dupain, Photography and Australian Culture, 1919-1939. Mulgrave, Vic.: Peleus Press in association with the National Gallery of Victoria, 2004; Dupain, Diana. 'Maxwell Spencer Dupain.' Sydneian 329 (1993): 458-60; Dupain, Max. 'Australian Camera Personalities: Max Dupain.' Contemporary Photography (January-February 1947): 15-16, 56-59; Dupain, Max. Max Dupain. Edited and with Biographical Essay by Gael Newton. Sydney: David Ell Press, 1980; Dupain, Max. Max Dupain's Australia. Ringwood, Vic.: Viking, 1986; Lakin, Shaune. Max and Olive: The Photographic Life of Olive Cotton and Max Dupain. Canberra: National Gallery of Australia, 2016. Exhibition catalogue; Max Dupain - Modernist. Curated by Avryl Whitnall. Sydney: State Library of New South Wales, 2007. Exhibition catalogue; Max Dupain on Assignment. Canberra: National Archives of Australia in association with Noel Butlin Archives Centre, Australian National University, 2007; Max Dupain: Photographs. Curated by Helen Ennis and Kylie Scroope. Canberra: Australian National Gallery, 1991. Exhibition catalogue; Personal knowledge of $A D B$ subject; White, Jill. Dupain's Australians, text by Frank Moorhouse. Neutral Bay, NSW: Chapter \& Verse, 2003.

HeLEN ENNIS

\section{DURACK, DAME MARY GERTRUDE}

(1913-1994), writer, was born on 20 February 1913 in Adelaide, second of six children of New South Wales-born Michael Patrick Durack [q.v.8], pastoralist, and his South Australianborn wife Bessie Ida Muriel, née Johnstone. Mary spent her infancy on the family's East Kimberley cattle stations, Argyle Downs and Ivanhoe. About 1917 she moved to Perth with her mother and siblings; her father was an occasional visitor from his pastoral duties. She was educated at Claremont Practising School and then Loreto Convent (1920-29), where she excelled at English and history. Recognising her flair for poetry and creative writing, her parents published a small book of her verse, Little Poems of Sunshine, in 1923.

Drawn by a desire to return to the Kimberley, Durack elected not to sit for her Leaving certificate examinations and spent 1931 at Argyle Downs. After her return to Perth, she contributed articles to the Western Mail and the West Australian, her principal subjects being the Aboriginal people who lived and worked on the Durack properties. In 1933 she and her younger sister Elizabeth travelled back to the Kimberley, where they worked as 
cooks and general hands. The sisters published All-About (1935), a light-hearted account of the mainly Miriwoong Aboriginal community at Argyle Downs. Two children's stories followed: Chunuma (1936) and Son of Djaro (1937). With their savings supplemented by royalties, Mary and Elizabeth voyaged to England in May 1936, also visiting Ireland, Europe, and North Africa, before returning to Perth in February 1937. Mary took a job in the city with the Western Mail, writing a column for country readers under the penname 'Virgilia' and a page for children as 'Aunt Mary'.

On 2 December 1938, at the office of the government statist, Melbourne, Durack married Horatio (Horrie) Clive Miller [q.v.10], an aircraft engineer and a renowned aviator; the couple had met when he travelled north in 1934 . With her husband mostly absent developing his airline venture, MacRobertson-Miller Aviation Co. Ltd, she resumed freelance writing while raising a family at their Nedlands, Perth, home. She published a series of children's booksPiccaninnies (1940), The Way of the Whirlwind (1941), and The Magic Trumpet (1946) which were illustrated by Elizabeth.

Dividing her time between Perth and Broome, where her husband had bought a house, Durack completed her first novel, Keep Him My Country (1955). The book's main theme was the relationship between an Aboriginal woman and a white pastoralist. Three years later she wrote the libretto for Dalgerie, the composer James Penberthy's opera version of the work, which would be performed at the Sydney Opera House in 1973. Her next book, Kings in Grass Castles (1959), was an instant success and established her as an author of repute; it has been republished many times since. Combining her skills as an imaginative storyteller with detailed family archival research, the book relates the history of her ancestors' departure from Ireland, their establishment at Goulburn, New South Wales, and migration first to western Queensland and then to the Kimberley.

Throughout her career, Durack produced book reviews and articles, as well as poetry, radio plays, and talks. With Elizabeth she completed four more children's books. In 1969 she published The Rock and the Sand, judged by many to have been her finest historical work, which portrayed the emerging, often fraught, relationships between Kimberley Aboriginal people ('people of the dream') and Catholic missionaries ('people of the clock') (Durack 1969, 21). Swan River Saga (c. 1972), a play she co-authored with the actress Nita Pannell [q.v.], drew on the letters and journals of Eliza Shaw, who arrived at the settlement in 1830 . Shaw's story became To Be Heirs Forever (1976), her only major book not set in the Kimberley.

Durack regularly returned to the north, principally to visit the Miriwoong people, most of whom had been displaced to Kununurra following the award of equal wages in 1972. The demise of the system of Aboriginal pastoral labour, combined with the inundation of Argyle Downs after the damming of the Ord River the same year, motivated her to resume work on the Durack family history. Her progress was delayed by Horrie's worsening health after a debilitating stroke in 1977. She also grieved the deaths of two of her daughters (in 1960 and 1975) and in 1979 was injured by a car when crossing a road, and required a lengthy period of rehabilitation. She eventually completed Sons in the Saddle in 1983. Using the diaries and letters of her father, and oral history material from Aboriginal people, the book tells the history of the family stations under the management of the second generation of Duracks. The same year she published her best-known poem, 'Lament for the Drowned Country', in which she imagined the voice of a Miriwoong woman, Maggie Wallaby, mourning the loss of her traditional lands under the waters of Lake Argyle.

Having been appointed OBE in 1966, Durack was promoted to DBE and awarded an honorary doctorate of letters by the University of Western Australia in 1977. She had been a foundation member of the Fellowship of Australian Writers, Western Australian section, in 1938 (president 1959-61 and 1966-67; life member 1967), and an executive member of the Aboriginal Theatre (later Cultural) Foundation (196976). Reflecting her interests in literature and history, she was a member of the Royal Western Australian Historical Society and the Australian Society of Authors, and the State branches of the National Trust of Australia 
and the Society of Women Writers. She was a patron of the Friends of the Battye [q.v.7] Library and of the Australian Stockman's Hall of Fame and Outback Heritage Centre (founding director 1976). In 1989 she was appointed AC.

Among the twenty-eight books Durack authored or co-authored, Kings in Grass Castles, The Rock and the Sand, and Sons in the Saddle are regarded as Australian literary classics. She has been widely praised for her narrative skills and for her willingness to portray Aboriginal people and European women as protagonists in the history of northern Australian colonisation. Some, though, have dismissed her as an apologist for the 'squattocracy', and for trivialising the role of Aboriginal people in its pastoral enterprises. She has also been accused of concealing violence on the Kimberley frontier through her celebration of the achievements of her forebears (Owen 2017, 30). Others have suggested that it was her success in enunciating the 'lasting ideology of paternal responsibility' that elevated her books to 'classical status in Euro-Australian culture' (Rowse 1987, 97). The anthropologist Bruce Shaw recognised the evolution of her views on Aboriginal people, from the 'affectionate paternalism' and 'unconscious stereotypes' in All-About, to the deeper, sympathetic understandings of her later works (1983, 1617). She enthusiastically promoted Aboriginal participation in the arts and literature, and would come to support land rights, advocating 'vesting of pastoral properties in Aboriginal communities' (Millett and Millett 2000, xiii).

A respected figure in the national and State literary and cultural spheres, Durack was modest about her achievements, and believed she had never reached her full potential as a writer. She was generous in her support of aspiring authors, and cultural and literary organisations, the time she devoted to others often being at the expense of her own work. With a wide circle of friends, she loved to entertain; at heart she was a homely person, devoted to her family. Despite declining health from the effects of abdominal cancer, she continued to write and to attend public engagements. She managed a final trip to the Kimberley in 1993. Dame Mary died in her home at Nedlands on 16 December 1994, survived by her two sons and two of her four daughters. After a requiem Mass at St Mary's
Cathedral, Perth, she was cremated; her ashes were buried in the garden at the Argyle Downs Homestead Museum, near her now-inundated 'spirit country'.

Bolton, Geoffrey. 'Writer Forged Image of Pastoral Age.' Australian, 20 December 1994, 13; Durack, Mary. Interview by Hazel De Berg, 12 March 1976. Transcript. Hazel de Berg collection. National Library of Australia; Durack, Mary. The Rock and the Sand. London: Constable, 1969; Durack Miller, Mary. Interview by Stuart Reid, 1990-91. Battye Library collection. National Library of Australia; Grant, Don. 'Mary Durack.' In Dictionary of Literary Biography. Vol. 260, Australian Writers, 1915-1950, edited by Selina Samuels, 106-15. Farrington Hills, MI: Thomson Gale, 2002; Greer, Germaine. Whitefella Jump Up: The Shortest Way to Nationhood. London: Profile Books, 2004; Millett, Patsy. 'Mary Durack: The Diarist.' Early Days. Journal of the Royal Western Australian Historical Society (Inc.) 13, no. 5 (2011): 678-96; Millett, Patsy, and Naomi Millett, eds. Pilgrimage: A Journey Through the Life and Writings of Mary Durack. Sydney: Bantam, 2000; Niall, Brenda. True North: The Story of Mary and Elizabeth Durack. Melbourne: Text Publishing, 2012; Owen, Chris. 'Every Mother's Son Is Guilty': Policing the Kimberley Frontier of Western Australia 1882-1905. Crawley, WA: UWA Publishing, 2017; Puchy-Palmos, Alison. 'Dame Mary Durack 1913-1994.' Westerly, no. 1 (Autumn 1995): 5-6; Rowse, Tim. "Were You Ever Savages?” Aboriginal Insiders and Pastoralists' Patronage.' Oceania 58, no. 2 (December 1987): 81-99; Shaw, Bruce. Banggaiyerri: The Story of Jack Sullivan. Canberra: Australian Institute of Aboriginal Studies, 1983; State Library of Western Australia. MN 71, Durack Family Papers, 1886-1991.

Malcolm Allbrook 
This text is taken from Australian Dictionary of Biography, Volume 19: 1991-1995 (A-Z), edited by Melanie Nolan, published 2021 by ANU Press, The Australian National University, Canberra, Australia.

doi.org/10.22459/ADB19.D 